\title{
Commercialism, subsistence, and competency on the Western Virginia frontier, 1765-1800
}

John M. Boback

West Virginia University

Follow this and additional works at: https://researchrepository.wvu.edu/etd

\section{Recommended Citation}

Boback, John M., "Commercialism, subsistence, and competency on the Western Virginia frontier, 1765--1800" (2000). Graduate Theses, Dissertations, and Problem Reports. 681.

https://researchrepository.wvu.edu/etd/681

This Thesis is protected by copyright and/or related rights. It has been brought to you by the The Research Repository @ WVU with permission from the rights-holder(s). You are free to use this Thesis in any way that is permitted by the copyright and related rights legislation that applies to your use. For other uses you must obtain permission from the rights-holder(s) directly, unless additional rights are indicated by a Creative Commons license in the record and/ or on the work itself. This Thesis has been accepted for inclusion in WVU Graduate Theses, Dissertations, and Problem Reports collection by an authorized administrator of The Research Repository @ WVU. For more information, please contact researchrepository@mail.wvu.edu. 


\section{Commercialism, Subsistence, and Competency on the Western Virginia Frontier, $1765-1800$}

\section{John M. Boback}

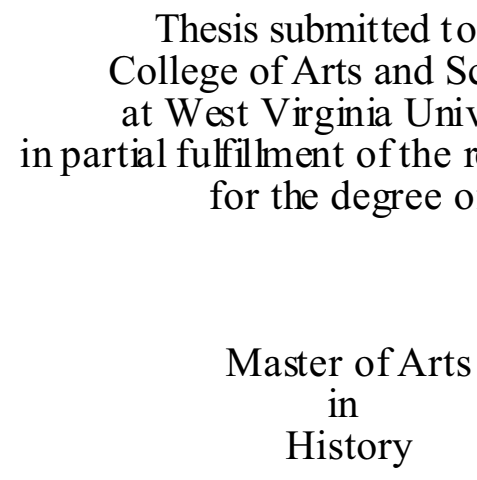

Ronald L. Lewis, Ph.D., Chair

Mary Lou Lustig, Ph.D.

A. Michal McMahon, Ph.D.

Department of History

Morgantown, West Virginia

2000

Keywo rds: Commercialism, Competency, Economics, Frontier, Subsistence, West Virginia 


\section{ABSTRACT \\ Commercialism, Subsistence, and Compet ency \\ on the Western Virginia Frontier, $1765-1800$}

John M. Boback

Since the early nineteenth cent ury, Americans have frequently asso ciated the pioneers of the Appalachian Mountains with subsistence farming, economic independence, and a certain degree of hostility toward capitalism. This thesis dispro ves the myth of pione er self-sufficiency by demonstrating how the men and women who settled in western Virginia during the final third of the eighteenth century used a variety of tactics in their struggle to achieve a competency. Although subsistence activities, such as hunting and farming, undoubtedly held an important place in the backcountry domestic economy, the settlers also interacted with the commercial market as both producers and consumers of a wide range of commodities. In the final analysis, this thesis adds to the growing body of scholarship which challenges the concept of Appalachian exceptionalism. 


\section{Table of Contents}

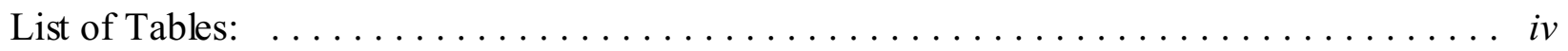

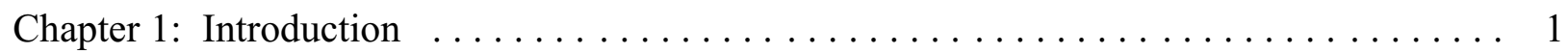

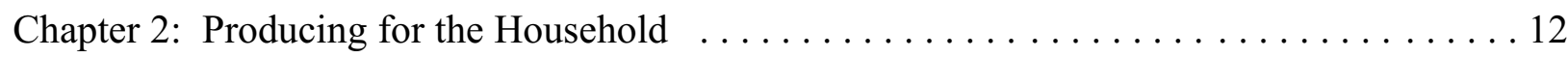

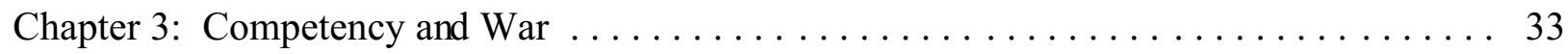

Chapter 4: Producing for the Market $\ldots \ldots \ldots \ldots \ldots \ldots \ldots \ldots \ldots \ldots \ldots \ldots \ldots \ldots \ldots \ldots$

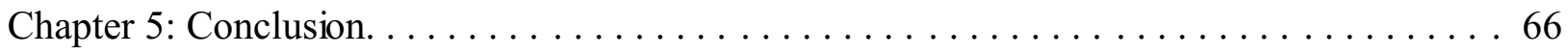

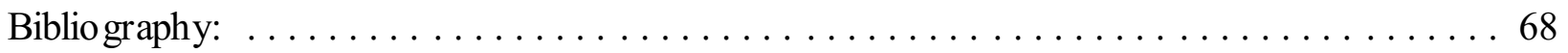

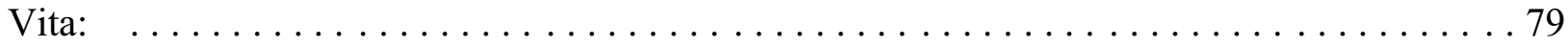




\section{List of Tables}

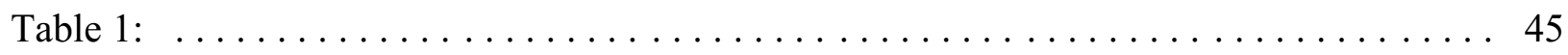

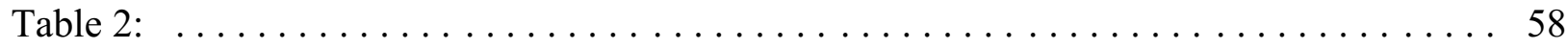

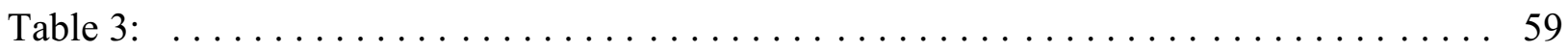

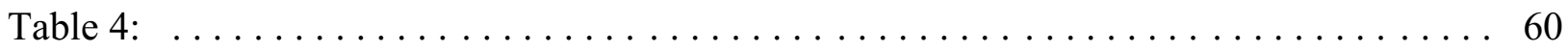

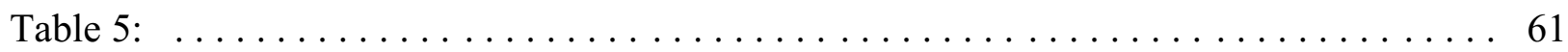




\section{Chapter One:}

Introduction

Americans have long been attracted to the pioneer image. Rugged, brave, larger than life, these stalwart men and women left behind friends and family to venture westward in search of adventure and what they hoped would be better lives. Through hard work and perseverance, they overcame Indians, wild animals, and a host of other tribulations as they carved new homes out of the Appalachian wilderness. Isolated by the ruggedness of the land, the pioneers of popular imagination lived completely self-sufficient lives independent of the commercial conveniences available in eastern cities. Hand hewn log cabins, spinning wheels, home tanned buckskin shirts, and butter churns all came to be associated with the economic independence, work ethos, and sense of self-sufficiency possessed by these supposedly exceptional individuals. In time, this image of the pioneer became symbolically significant as representative of the American national character. ${ }^{1}$

Although Americ ans have long been at tracted to the myth of pioneer self-sufficiency, it has little basis in historical fact. ${ }^{2}$ The purpose of this study is to explore the domestic economy of the settlers as manifested in western Virginia during the final third of the eighteenth century. More specifically, I seek to dispel the myth of pioneer self-sufficiency by demonstrating how the settlers employed both subsistence and commercial modes of production in the support of their households. I also emphasize that the settlers did not live in economic isolation. Although the backwoods settlements of western Virginia may have been physically remote, they were not

${ }^{1}$ Elizabeth A. Perkins, "The Consumer Front ier: Household Consumption in Early Kentucky," The Journal of American History 78 (1991): 486.

${ }^{2}$ For the purposes of this thesis, the term self-sufficient is defined as being "able to maintain oneself . . . without outside aid." Webster's Ninth New Collegiate Dictionary, s. v. "selfsufficient." 
isolated. ${ }^{3}$ Many external forces exerted an influence on the economic activities of the settlers. Fluctuations in the world economy, disruptions in trade due to the Revolutionary War, destruction caused by Indian attacks, changes in overseas demands for backcountry commodities, and the ruggedness of the landsc ape all served to promote some economic activities while discouraging others.

At this point, it would be beneficial to define and explain a few of the economic terms as used in this thesis.

"Subsistence economics" involves the production of goods and services for the express consumption of the producers and their families. Involvement with the marketplace is very limited and plays a minor role in meeting the family's material requirements. ${ }^{4}$ Hunting wild game or gathering chestnuts to feed one's family are examples of subsistence activities. Additionally, building one's own log cabin or spinning and weaving linsey-woolsey to clothe one's children also falls within the realm of subsistence economics.

"Commercial economics" is the production of goods and services destined for exchange in the competitive market. The principle of supply and demand is in effect. ${ }^{5}$ Bartering deer skins at a trading post or selling agricultural products at a county market are examples of commercial activities.

"Capitalism" is a particular type of commercial economic production in which workers neither own the means of production nor do they have a share in the goods or services they produce. As compensation for their labor, the workers receive a wage. In capitalist economics, labor is considered a commodity. ${ }^{6}$ An example of backcountry capitalism can be seen in the glass

${ }^{3}$ David C. Hsiung, "How Isolated Was Appalachia?: Upper East Tennessee, 1780-1835," Appalachian Journal 16 (1989): 336; Gene Wilhelm, Jr., "Appalachian Isolation: Fact or Fiction?," in An Appalachian Symposium: Essays Written in Honor of Cratis D. Williams, ed. J. W. Williamson (Boone, N. C.: Appalachian State University Press, 1977), 83.

${ }^{4}$ Arthur Getis, Judith Getis, Jerome D. Fellmann, Introduction to Geography, 6th ed. (Boston: McGraw-Hill Higher Education, 1998), 355-58, 526.

${ }^{5}$ Ibid., 355-56, 516.

${ }^{6}$ Maurice Dobb, Studies in the Development of Capitalism (New York: International Publishers, 1947), 7-8, 10. 
factory built by Albert Gallatin in 1794. In addition to employing a book-keeper and clerk, he also hired six German glass workers to operate his facility. ${ }^{7}$ In contrast, a blacks mith with a backyard shop who sells hand-forged nails directly to his neighbors is not involved in a capitalist enterprise because he owns his own tools, the goods he produces, and works for himself. On the other hand, if the same blacksmith were to expand his operation by employing additional smiths to work in his shop under his direction, the shop would then become involved in capitalist production.

The myth of pioneer self-sufficiency has a long and interesting history. During the Revolutionary era, republicans under the intellectual leadership of Thomas Jefferson advocated a national economic policy which favored small independent farms over urban manufacturing. The concept, however, was not unique to Jefferson. Contemporary French Physiocrats, such as Du Pont de Nemours, also touted agrarian-centered economics as being the source of true wealth and public welfare in a country. ${ }^{8}$ Jefferson, however, injected a philosophical element into his proagrarian argument. Hearkening back to Aristotle who had drawn a connection between democracy and agriculture, Jefferson posited that republican virtue thrives where the people earn their subsistence by working close to the land. ${ }^{9}$ In a letter to John Jay, Jefferson explained that "Cultivators of the earth are the most valuable citizens. They are the most vigorous, the most independent, the most virtuous, and they are tied to their country, and wedded to its liberty. . . "10

Conversely, Jefferson perceived industrial manufacturing as a threat to the independence and virtue of a country. The problem with industry, according to Jefferson, is that people so employed eventually become dependent upon the whims of their customers. In time, this

${ }^{7}$ Franklin Ellis, History of Fayette County (Philadelphia: L. H. Everts, 1882), 768-69.

${ }^{8}$ A. Whitney Griswold, Farming and Democracy (New Haven: Yale University Press, 1948), 21-22.

${ }^{9}$ Thomas Jefferson, Notes on the State of Virginia, ed. William Pedan (New York: W. W. Norton, 1954), 165.

${ }^{10}$ Quoted in Griswold, Farming, 31. 
dependence begets subservience which "suffocates the germ of virtue." Not only does this occur on a personal scale, but it also takes place on the international level. Jefferson feared that if the United States were to become a major indus trial producer, its citizens would eventually become dependent on their overseas consumers. Only by embracing agriculture could the United States hope to remain a free and virtuous nation. ${ }^{11}$

The pioneer farmers who settled Appalachia during the late eighteenth century figured heavily into Jefferso n's vision of an expansive republican America. Fundamental to his overall design was the as sumption that the pioneers primarily lived and worked on small self-sufficient farms. Uncontaminated by industry, commercialism, or urban living, the pioneers and the ir descend ants would institute republican structures wherever they happened to settle, thus ensuring that the expanding United States would remain a democracy governed by virtue. In his capacity as a politician, Jeffers on worked diligently to transform his theory into reality by promoting governmental policies that favored both agriculture and territorial expansion. Not only did he help to open the Northwest Territory to settlement by laying the groundwork for the Northwest Ordinance of 1787 , but he also created the system by which western territories could be admitted to the Union as new states. Perhaps his most noteworthy accomplishment along this vein was the Louisiana Purchase of 1803 which effectively doubled the amount of territory open to farmers. ${ }^{12}$ For Jefferson, the small independent farmer was the key to America's future political and econo mic independence. Although industrialization in the early nineteenth century ended any chance of Jefferson's agrarian vision becoming a reality, the romant ic ideal of the self-sufficient farmer persisted in the American psyche. ${ }^{13}$

By the late nineteenth century, the mythical image of the self-sufficient farmer had been reoriented in the minds of Americans to look backwards in time rather than forward. In the face

\footnotetext{
${ }^{11}$ Jefferson, Notes, 165.
}

${ }^{12}$ Henry Nash Smith, Virgin Land: The American West as Symbol and Myth (Cambridge: Harvard University Press, 1950), 128-29; Noble E. Cunningham, Jr., In Pursuit of Reason: The Life of Thomas Jefferson (New York: Ballantine Books, 1987), 85.

${ }^{13}$ Joyce Appleby, Capitalism and a New Social Order: The Republican Vision of the 1790s (New York: New York University Press, 1984), ix. 
of uncertainties such as industrial capitalism, mechanization, urbanization, and large scale immigration, Americans sought psychological refuge in a romanticized agrarian past. ${ }^{14}$

The image of the virtuous self-sufficient pioneer has held great sway in modern America. Even respected scholars and historical writers have at times fallen prey to the fabricated concept. In their writings, the trans-Allegheny settlers have often been portrayed as having no desire to participate in the market economy. Completely satisfied with a simple subsistence lifestyle, they eschewed such concepts as commercial economics and the accumulation of capital wealth. Popular historian Dale Van Every, for example, claimed that most settlers were motivat ed "by no more than a hope of proving able to win a bare subsistence from the raw new land." ${ }^{15}$ Writing along similar lines, historian John Caruso asserted that the pioneers "gave little consideration to wealth, position, and family tradition." ${ }^{16}$ Sociologist Thomas Ford went one step further when he equated subsistence economics with success by arguing that on the frontier, "complete economic independence was the mark of a successful man."17

The problem with this interpretation is that it is inconsistent with the historical record. In each of the above examples, the writer failed to substantiate his assertion by citing tax records, estate inventories, or other eighteenth century do cuments. Caruso, in fact, has been specifically singled out as having based some of his assertions more on preconceived notions and romanticized images than documentable fact. ${ }^{18}$ Although he was cognizant of the dangers inherent in romanticism, he no netheless fell victim to its appeal. On Caru so's frontier, boys developed the ability to walk through the autumn forest without crushing a leafor snapping a

${ }^{14}$ Perkins, "Consumer," 486.

${ }^{15}$ Dale Van Every, Forth to the Wilderness: The First American Frontier, 1754-1774 (New York: Morrow, 1961), 210.

${ }^{16}$ John Anthony Caruso, The Appalachian Frontier: America's First Surge Westward (Indianapolis: Bobbs-Merrill, 1959), 208.

${ }^{17}$ Thomas R. Ford, "The Passing of Provincialism," in The Southern Appalachian Region: A Survey, ed. Thomas R. Ford (Lexington: University of Kentucky Press, 1962), 12.

${ }^{18}$ Michael J. Puglisi, "Introduction," in Diversity and Accommodation: Essays on the Cultural Composition of the Virginia Frontier, ed. Michael J. Puglisi (Knoxville: University of Tennessee Press, 1997), 4-5. 
twig. They could also discern the difference between the report of an Indian's gun and that of a white man. Caruso presented the pioneers as being a fiercely independent, heroic breed of men who subsisted off the land with little regard or need for the established commercial institutions of the East. ${ }^{19}$ Although such an image is appealing, it has little basis in fact.

Even a cursory survey of first hand accounts of pione er life in western Virginia reveals the presence of commercial attitudes. Consider, for example, Morgantown resident No ah Linsly who in a 1798 letter to his brothers described what he perceived to be the commercial opportunities of the Monongahela backcountry. He wrote that "the land is . . good, but very hilly, better adapted to grass and the raising of stock than for any other purpose." He added that cattle could be driven from the Morgantown area to the markets of Alexandria and Baltimore, but that wheat flour would have to be shipped down the Ohio and Mississippi rivers to New Orleans. ${ }^{20}$

Another example is found in settler William Scripps who in 1792 moved to the upper Monongahela Valley where he hoped to establish a prosperous plantation. Already a man of some means, he brought with him "his chest of books and clothing, mahogany tables, cushion chairs, high post bed steads and even large flat boxes of window glass." He also employed and brought with him skilled mechanics "to form a little colony on his estate and carry on business under his patronage." Although the reality of life on the frontier ultimately frustrated Scripps' grand scheme, he nonetheless exemplifies the entrepreneurial spirit found in many frontier settlers. Not only did he attempt commercial agriculture, he also employed skilled workers in what may have been a capitalistic relationship. Whether Scripps actually owned his workers' tools (the means of production) and paid them a wage is not documented. ${ }^{21}$ Together, these two examples indicate that the concept of commercialism was not entirely foreign to the settlers of transAllegheny Virginia.

${ }^{19}$ Caruso, Appalachian, 207-208, 232.

${ }^{20}$ Gibson Lamb Cranmer, ed., History of Wheeling City and Ohio County, West Virginia and Representative Citizens (Chicago: Biographical Publishing Company, 1902), 223-24.

${ }^{21}$ Earl L. Core, The Pioneers, vol. 2 of The Monongalia Story: A Bicentennial History (Parsons, W.Va.: McClain, 1976), 297, 231-32. 
Since the 1970s, numerous scholars examining similar original sources have concluded that the alleged anti-commercial attitude of the pioneers has been greatly exaggerated. ${ }^{22}$ Otis Rice in his two books The Allegheny Frontier and The History of Greenbrier County demonstrated that many settlers had a vested interest in commercial endeavors, such as the fur and ginseng trade, land speculation, and commercial agriculture. ${ }^{23}$ Historical geographer Robert D. Mitchell in his book Frontier Commercialism arrived at a similar conclusion about the settlers of the Shenandoah Valley. In fact, he found commercialism to be "the most dynamic element in the emerging pioneer economy." Not only did settlers in the Valley supply commodities to their local market, but they also established widespread trading contacts throughout the Atlantic community via the ports of Alexandria and Philadelphia. ${ }^{24}$

Richard MacMaster in his study, "The Cattle Trade in Western Virginia, 1760-1830," found that by the 1750s, the commercial economy had expanded westward out of the Shenandoah Valley into the eastern foothills of the Allegheny Mountains. All along the South Branch of the Potomac River, enterprising settlers such as Matthew Patton practiced commercial cattle grazing. Of particular interest is the fact that many of these back country cattlemen embraced progressive practices such as corn feeding and selective breeding. ${ }^{25}$ By no means was frontier commercialism limited to production. Elizabeth Perkins in "The Consumer Frontier" found that stores, traders, and consumer goods had been present in frontier Kentucky from the earliest days of white

\footnotetext{
${ }^{22}$ Paul Salstrom, "Economic History of West Virginia: A Critical Essay," in West Virginia History: Critical Essays on the Literature, ed. Ronald L. Lewis and John C. Hennen, Jr. (Dubuque, Iowa: Kendall/Hunt, 1993), 77.

${ }^{23}$ Otis K. Rice, The Allegheny Frontier: West Virginia Beginnings, 1730-1830 (Lexington: University Press of Kentucky, 1970); Otis K. Rice, A History of Greenbrier County (Lewisburg, W.Va.: Greenbrier Historical Society, 1986).

${ }^{24}$ Quoted in Paul Salstrom, Appalachia's Path to Dependency: Rethinking a Region's Economic History, 1730-1940 (Lexington: University Press of Kentucky, 1994), 6; Robert D. Mitchell, Commercialism and Frontier: Perspectives on the Early Shenandoah Valley (Charlottesville: University Press of Virginia, 1977).

${ }^{25}$ Richard K. MacMaster, "The Cattle Trade in Western Virginia, 1760-1830," in Appalachian Frontiers: Settlement, Society, and Development in the Preindustrial Era, ed. Robert D. Mitchell (Lexington: University Press of Kentucky, 1990).
} 
settlement in the mid-1770s. ${ }^{26}$ With such an overwhelming body of evidence in support of frontier commercialism, it becomes understandable how historical sociologist Wilma Dunaway could conclude that "settler Appalachia was born capitalist." In fact, she even went so far as to argue in her book, The First American Frontier, that "it is historically and theoretically inappropriate to categorize the region's inhabitants as precapitalist."127

Although it has now been well established that some, if not most, settlers engaged in commercial economics, it would be a mistake to assume that commercialism totally dominated their lives in the way it does for most modern Americans. Exaggerating the importance of commercial production, while denying the significance of subsistence economics, creates a distorted image of the settlers' domestic economy. It is important to understand that subsistence and commercial economic systems are not mutually exclusive. Rather, they both function simult aneously in varying degrees within virtually every household in every society. ${ }^{28}$ Perhaps the best way to conceptualize the relationship between the two systems is to envision them as being on oppo site ends of a continuum. ${ }^{29}$ No white settler lived a purely subsistent or commercial lifestyle. ${ }^{30}$ Rather, their household economies fell somewhere on the continuum between both extremes. Every settler on the western Virginia frontier, in varying degrees, pursued both subsistence and commercial endeavors. This combination of modes of production reflects the idea that the late eighteenth century was a transitional period in which the American economy was "clearly not feudal and not yet fully capitalist."131

${ }^{26}$ Perkins, "Consumer," 489.

${ }^{27}$ Wilma A. Dunaway, The First American Frontier: Transition to Capitalism in Southern Appalachia, 1700-1860 (Chapel Hill: University of North Carolina Press, 1996), 16.

${ }^{28}$ Getis, Introduction, 356.

${ }^{29}$ Ronald L. Lewis, Transforming the Appalachian Countryside: Railroads, Deforestation, and Social Change in West Virginia, 1880-1920 (Chapel Hill: University of North Carolina Press, 1998), 23.

${ }^{30}$ James T. Lemon, The Best Poor Man's Country: A Geographical Study of Early Southeastern Pennsylvania (Baltimore: Johns Hopkins Press, 1972), 27.

${ }^{31}$ Allan Kulikoff, "The Transition to Capitalism in Rural America," William and Mary Quarterly 3d ser., 46 (1989): 140. 
As an aid to understanding the structure of the settlers' ho usehold econo mies, I have employed "competency" as a theoretical model. In the early modern period, the term competency referred to a comfortable standard of living somewhat above the level of mere survival. ${ }^{32}$ The Oxford English Dictionary defines the term as "a sufficiency, without superfluity, of the means of life . . . a sufficient income; easy circumstances." ${ }^{133}$ Unlike fully developed capitalism, the pursuit of competency does not involve the endless accumulation of wealth. ${ }^{34}$ Rather, when a family has achieved a competent standard ofliving, the desire to continue working diminishes. For example, William Wood observed in 1634 that despite the crudeness oflife in New England, the colonists were "well-contented, and looke not so much at abundance, as a competencie."135

Competency did not connote a uniform standard which everyone aspired to achieve. People differed in what they considered a competent lifestyle. ${ }^{36}$ An educated backcountry entrepreneur such as Albert Gallatin aspired to a higher level of comfort and refinement than a professional hunter such as Meshach Browning. The diffe rence in their concept of competency is evidenced by their homes. While Gallatin's home consisted of a multi-story stone manor house named Friendship Hill, Browning opted to live in a log cabin that "had neither floor, chimney, nor door -- a hole cut through the wall being the only way of getting in or out." ${ }^{37}$ Socio-economic class, education level, occupation, family responsibilities, reputation, societ al expectations, and personal preference all helped to determine a person's concept of competency.

\footnotetext{
${ }^{32}$ Daniel Vickers, "Competency and Competition: Economic Culture in Early America," William and Mary Quarterly, 3d ser., 47 (1990): 3-4.

${ }^{33}$ The Oxford English Dictionary, 2d ed., s.v. "competency."

${ }^{34}$ Rex Burns, Success in America: The Yeoman Dream and the Industrial Revolution (Amherst: University of Massachusetts Press, 1976), 1.

${ }^{35}$ Vickers, "Competency," 3, 12. See also Andrew R. L. Cayton, "Marietta and the Ohio Company," in Appalachian Frontiers: Settlement, Society, and Development in the Preindustrial Era, ed. Robert D. Mitchell (Lexington: University Press of Kentucky, 1990), 194-95.

${ }^{36}$ Vickers, "Competency," 3.

${ }^{37}$ Minnie Kendall-Lowther, Friendship Hill: Home of Albert Gallatin (Morgantown, W. Va.: Friendship Hill Association, 1928); Meshach Browning, Forty-Four Years of the Life of a Hunter (Winston-Salem, N. C.: Winston Printing Company, 1942), 103.
} 
By no means did a person's sense of competency necessarily remain static over the course of his life. Changing circumstances frequently caused people to reassess what they believed was necessary to achieve competency. ${ }^{38}$ For example, the material requirements of settler Jacob Prickett changed between 1772 and 1790 when he went from having thirteen people in his household to being a sixty-eight year old widower with adult children. ${ }^{39}$ Social mobility also influenced competency. In 1784, the Harrison County Court appointed settler William Haymond, Sr. to the position of county surveyor. Prior to assuming his new post, Haymond was required to pass a qualifying exam at William and Mary College. In preparation for his trip to Williamsburg, he bought a new coat that made him "proud, as no other person had one" like it. ${ }^{40}$ His purchase of the coat was an outward manifestation of his rising sense of competency. As a frontiersman, Haymond's old coat was probably sufficient, but when he became an important county official he likely perceived a need to wear clothing commensurate to his elevated social status.

Seeking a competency did not preclude commercial endeavors. After all, competency is not synonymous with subsistence. When the settlers looked for ways to achieve their competencies, they employed both subsistence and commercial modes of economic production. In many cases, a particular re source (commodity) had value not only within the household, but also on the commercial market. Comparative historian Paul Salstrom pointed out that "no contradiction existed between market farming and ... subsistence farming." Livestock and grain, for example, "were just as suitable for supplying outside markets as they were for home consumption."11 By the same token, forest products, such as deer skins, could also be used either domestically or sold on the commercial market. In short, competency is best envisioned as an econo mic objective

\footnotetext{
${ }^{38}$ Vickers, "Competency," 3.
}

${ }^{39}$ L'lora C. McDaniel, The History and Genealogy of the Ancestors of John M. Tomey and Catharine M. Prickett and Their Descendants (n.p.,n.d), 37, 45; J. Miles Prickett Papers, Prickett's Fort Memorial Foundation Archives, Fairmont, West Virginia.

${ }^{40}$ William Haymond, Jr. to Luther Haymond, 18 February 1842, William Haymond, Jr. Papers, West Virginia Regional and History Collection, West Virginia University.

${ }^{41}$ Salstrom, Appalachia's, xiv; Paul Salstrom, "Subsistence-Barter-and-Borrow Systems: An Approach to West Virginia's Economic History," West Virginia History, 51 (1992): 46. 
while commercial and subsistence modes of production are merely means of achieving that end. Hopefully, this study will contribute to our understanding of the role that both economic systems played in the domestic economies of the trans-Allegheny settlers. 


\section{Chapter Two:}

Pro ducing for the Household

When the first settlers crossed the threshold of the Allegheny Mountains into western Virginia, they encountered a land abundant in natural resources. Save for a scattering of mountain glades and old Indian fields in varying stages of regrowth, a vast forest of tall straight trees completely covered the hills and mountains of the region. Within the forests lived a diversity of animal life including white-tailed deer, elk, black bears, turkeys, mountain lions, beavers, gray wolves, and even small herds of buffalo. The nutrient-rich soil, particularly in the river and creek bottoms, was conducive to mixed agriculture and livestock grazing. ${ }^{2}$ The land supported a rich abundance of native edible flora including strawberries, blackberries, chestnuts, walnuts, hickory nuts, pawpaws, sarvis berries, wild plums, wild grapes, wild cherries, ramps, and the syrup producing sugar maple. ${ }^{3}$ Beneath the surface of the ground lay rich mineral resources, such as coal, oil, limestone, clay, sand, iron ore, and salt. ${ }^{4}$ In many ways, western Virginia was a hunter/gatherer's paradise.

A common theme in the writings of the early pion eers was the econo mic potential of this new land. In 1671, Thomas Batts and Robert Fallom crossed the Allegheny Mount ains exploring as far west as Tug Fork near the present city of Matewan, West Virginia. ${ }^{5}$ In his short journal, Fallom referred to the quality of the soil no fewer than seven times. Near the Blue Ridge in eastern Virginia, he found "very stony rocky ground," however, by the time the expedition had

${ }^{1}$ Roy B. Clarkson, Tumult on the Mountains: Lumbering in West Virginia, 1770-1920 (Parsons, W. Va.: McClain, 1964), 1-12.

${ }^{2}$ L. Diane Barnes, "Avenues to a Market Economy: Harrison County, West Virginia, to 1860" (Master's thesis, West Virginia University, 1995), 3, 10-11.

${ }^{3}$ Joseph Doddridge, Notes on the Settlement and Indian Wars (1912: reprint, Parsons: W. Va.: McClain, 1976), 70-75.

${ }^{4}$ Michael E. Workman, "Political Culture and the Coal Economy in the Upper Monongahela Region: 1776-1933" (Ph.D. diss., West Virginia University, 1995), 52-53.

${ }^{5}$ Alan Vance Briceland, Westward from Virginia: The Exploration of the VirginiaCarolina Frontier, 1650-1710 (Charlottesville: University Press of Virginia, 1987), 134, 144. 
reached Tug Fork, the soil was "very rich."6 Settler Joseph Doddridge similarly noted that throughout western Virginia, "a fruitful soil . . supplies abundantly all the wants of life."7 Other pioneers noticed the commercial value of the timber. Writing in his journal in 1746 , surveyor Thomas Lewis described the hills as being exceedingly well timbered. The spruce, cherry, beech, and maple trees were "the most and finest" he had ever seen with some being "three or four feet Diameter thirty or forty foot without a Branch." ${ }^{8}$ Settlers and explorers alike perceived this abundance of land and resources as an opportunity for material gain.

Nobody knows for sure when the first white pers on actually settled in trans-Allegheny Virginia. The first documented instance, however, occurred in 1749 when Stephen Sewell and Jacob Marlin built a cabin near the Greenbrier River in present Pocahontas County. Their tenure in western Virginia appears to have been very brief, however. Following a religious dispute, the two parted ways with Marlin eventually returning to the Shenandoah Valley and Sewell being killed by Indians. ${ }^{9}$

The impermanence of the Sewell/Marlin settlement was typical of the first generation of settlers in western Virginia. Although the physical remoteness of the region undoubtedly made occupation difficult, the greatest obstacle came from the nearly four thousand Shawnee Indians who by the time of white settlement lived primarily in Ohio, but regarded western Virginia as an integral part of their tribal hunting territory. ${ }^{10}$ Prior to white contact, the Shawnees had also lived

${ }^{6}[$ Robert Fallom], "Explorations Beyond the Mountains," William and Mary Quarterly, 1st ser., 15 (1907): 236-40.

${ }^{7}$ Doddridge, Notes, 21.

${ }^{8}$ Thomas Lewis, The Fairfax Line: Thomas Lewis' Journal of 1746 (New Market, Va.: Henkel Press, 1925), 39.

${ }^{9}$ Otis Rice, A History of Greenbrier County (Parsons, W. Va.: Greenbrier Historical Society, 1986), 17; G. D. McNeill, Tales of Pocahontas County (Parsons: W. Va.: McClain, 1991), 1-3.

${ }^{10}$ Janet Hubbard-Brown, The Shawnee (New York: Chelsea House, 1995), 42, 44. 
in western Virginia, however, a combination of disease and intertribal warfare had forced them to abandon most of their communities east of the Ohio River. ${ }^{11}$

The diseases that decimated the Shawnee population during the seventeenth century originated among the English colonists who had settled at Jamestown. Archeologists suspect that Susquehannock hunters and traders inadvertently introduced these diseases to the Shawnees of western Virginia during hunting and trading expeditions. ${ }^{12}$ By the 1640 s, epidemics of measles, small pox, and a host of other virgin soil pathogens had begun to kill large numbers of Shawnees. Archeologists studying the site of a seventeenth century village in the Kanawha Valley discovered the existence of several mass graves with the largest one containing almost forty bodies. The researchers concluded that disease was the probable cause of death. ${ }^{13}$ Unfort unately, there is no way of determining precisely how much of a negative impact diseases had on the Shawnees' overall population. If one accepts that the Shawnees' early seventeenth century population ranged between 10,000 and 12,000, and if anthro pologist Jerry Clark's estimate that their population a century later ranged between 2,000 and 4,000 is correct, then it can be calculated that their population experienced a decline of somewhere between 40 and 83 percent over a hundred year period. ${ }^{14}$ This range is in line with the generally accepted estimate that introduced diseases caused mortality rates as high as 75 to 90 percent within some tribes. ${ }^{15}$

\footnotetext{
${ }^{11}$ Daniel B. Fowler, "An Old Shawnee Town in West Virginia," West Virginia Archeologist 28 (1979), 42.

${ }^{12}$ Stanley W. Baker, "Neale's Landing Site Ceramics: A Perspective on the Protohistoric Period from Blennerhassett Island," West Virginia Archeologist 40 (1988), 49-50; Michael B. Barber and Eugene B. Barfield, "Native Americans on the Virginia Frontier in the Seventeenth Century: Archeological Investigations along the Interior Roanoke River Drainage," in Diversity and Accommodation: Essays on the Cultural Composition of the Virginia Frontier, ed. Michael J. Puglisi (Knoxville: University of Tennessee Press, 1997), 148; Francis Jennings, "Susquehannock," in Northeast, vol. 15, Handbook of North American Indians (Washington, D.C.: Smithsonian Institution, 1978), 364.

${ }^{13}$ Ronald W. Moxley, "The Orchard Site," West Virginia Archeologist 40 (1988), 32.

${ }^{14}$ Jerry E. Clark, The Shawnee (Lexington: University Press of Kentucky, 1993), 3.

${ }^{15}$ See Colin G. Calloway, New Worlds for All: Indians, Europeans, and the Remaking of Early America (Baltimore: Johns Hopkins University Press, 1997), 33-41.
} 
Starting in 1662, the suffering of the Shawnee people increased when Iroquois warriors from present New York began raiding their villages. ${ }^{16}$ The reason for the Iroquois invasion is tied closely to the fur trade that had developed in the eastern Great Lakes region during the early seventeenth century. At white trading posts, the Iroquois traded beaver skins for commodities such as guns, knives, beads, cloth, to ols, alcohol, and brass kettles. Within just two generations, the Iroquo is' lifestyle had become dependent on having access to white trade goods. ${ }^{17}$ To obtain these goods, they needed furs. At first, the Iroquois hunted and trapped beavers within their own territory, however, by 1640 , the beaver population of New York teetered on the edge of extinction. With their own beavers gone, the Iroquois turned a covet ous eye tow ard the hunting grounds of their neighbors. Starting in the 1640s, they became embroiled in a series of wars that pitted them against one Indian neighbor after another. Collectively, these wars are known as the Beaver Wars, and they were fought to determine which tribe would dominate the fur trade. ${ }^{18}$

The Iroquois' attacks into the upper Ohio Valley totally disrupted the Indians that had been living there. The Shawnees particularly suffered from the invasion. By the late 1680s, their tribe had been shattered into several small bands. Some of them continued to live in the Ohio Valley under the nominal control of the Iroquois. Other Shawnees fled their tribal homeland for destinations as widespread as present Illinois, Alabama, Florida, and the Carolinas. ${ }^{19}$ The net result of the alien diseases and the Iroquois invasion of the Ohio Valley is that by the late sevent eenth century, western Virginia had a very sparse Indian population. ${ }^{20}$

${ }^{16}$ Charles Callender, "Shawnee," in Northeast, vol. 15, Handbook of North American Indians (Washington, D.C.: Smithsonian Institution, 1978), 630.

${ }^{17}$ Francis Jennings, The Ambiguous Iroquois Empire: The Covenant Chain Confederation of Indian Tribes with English Colonies from Its Beginnings to the Lancaster Treaty of 1744 (New York: W. W. Norton, 1984), 111.

${ }^{18}$ Paul A. W. Wallace, Indians in Pennsylvania (Harrisburg: Pennsylvania Historical and Museum Commission, 1961), 100-4.

${ }^{19}$ For a detailed examination of the migrations of the various Shawnee bands, see Clark, Shawnee, Ch. 2.

${ }^{20}$ Fowler, "Old," 24; Otis K. Rice, West Virginia: A History (Lexington: University Press of Kentucky, 1985), 9. 
The dispersal of the Shawnee nation did not last long. By the end of the seventeenth century, many of the Shawne es who had been living in present Illinois, South Carolina, and the Cumberland River of Tennessee began migrating toward eastern Pennsylvania. ${ }^{21}$ They, like other groups of refugee Indians, had heard stories of how William Penn and the pacifist Quakers treated all people with toleration. ${ }^{22}$ Penn told his followers "Don't abuse the [Indians], but let them have justice." This admonition was embodied in several Quaker policies that collectively created an environment that fostered go od relations between the Shawnees and Pennsylvanians. The Quakers maintained no army; they sent no missionaries among the tribes; the selling of alcohol to Indians was prohibited; and no settlement could take place on a tract of land unless it had been legally purchased from the Indians. ${ }^{23}$

Despite Penn's noble intentions, not every Pennsylvanian treated the Indians well. One of the chief abusers was Provincial Secretary James Logan who secretly used the power of his office to remove the Indians from choice pieces of land. ${ }^{24}$ Following Penn's death in 1718, abuses at the hands of whites became even more blatant. Settlers increasingly encroached on Indian lands without first purchasing them. ${ }^{25}$ In addition, the settler's free range cattle frequently destroyed the Indian's corn fields. ${ }^{26}$ In response to this increasing white pressure, the Shawnees decided that migration was the best solution to their problems. Between 1722 and 1734, most of the remaining Shawnees left eastern Pennsylvania and returned to their old tribal territory in the upper Ohio Valley. ${ }^{27}$ Greatly reduced in numbers and having suffered innumerable abuses at the hands

\footnotetext{
${ }^{21}$ Clark, Shawnee, 21-22.
}

${ }^{22}$ For a discussion of some of the other groups of refugee Indians who came to Pennsylvania, see Wallace, Indians, Ch. 14.

${ }^{23}$ Jennings, Ambiguous, 215, 241-44.

${ }^{24}$ Ibid., 248, 271.

${ }^{25}$ Wallace, Indians, 143.

${ }^{26}$ Jennings, Ambiguous, 272.

${ }^{27}$ Clark, Shawnee, 22. 
of the Iroquois and English, the Shawnees were determined by the 1750s to resist any new intrusion into their western Virginia hunting grounds.

Between 1749 and 1754, an estimated fifty-two white families attempted to settle in the Greenbrier and Tygart river valleys of western Virginia. ${ }^{28}$ In 1755, however, Shawnee warriors allied with the French attacked those settlements killing many and forcing the survivors to abandon their homesteads. By the end of the year, no white families remained in trans-Allegheny Virginia. ${ }^{29}$ When the French and Indian War ended, settlers returned to western Virginia only to be repulsed a second time during Pontiac's Uprising (1763-1765). By the end of 1766, settlers returned to trans-Allegheny Virginia for a third time. After almost twenty years of effort, they finally succeeded in establishing permanent settlements west of the mountains. ${ }^{30}$

By the early 1770 s, hundreds of pioneer families had settled in the Greenbrier, Monongahela, and Ohio river valleys. Traditionally, the ethnic group most often associated with the trans-Allegheny settlers has been the Scots-Irish. ${ }^{31}$ It would be a mistake, however, to envision the frontier population as being ethnically homogeneo us. Even a cursory survey of the families appearing in the 1782 Virginia census for Monongalia County reveals great diversity. ${ }^{32}$ For example, the Dragoo family was descended from French Huguenots; the Springers came to

${ }^{28}$ Otis K. Rice and Stephen W. Brown, West Virginia: A History, 2d ed. (Lexington: University Press of Kentucky, 1993), 20-21; Scott Alexander Withers, Chronicles of Border Warfare (1895; reprint, Parsons, W. Va.: McClain, 1989) 74-75.

${ }^{29}$ Otis K. Rice, The Allegheny Frontier: West Virginia Beginnings, 1730-1830 (Lexington: University Press of Kentucky, 1970), 41.

${ }^{30}$ Rice, Greenbrier, 28, 30.

${ }^{31}$ John Anthony Caruso, The Appalachian Frontier: America's First Surge Westward (Indianapolis: Bobbs-Merrill, 1959), 37; James G. Leyburn, The Scotch-Irish: A Social History (Chapel Hill: University of North Carolina Press, 1962), 256.

${ }^{32}$ Earl L. Core, The Pioneers, vol. 2 of The Monongalia Story: A Bicentennial History (Parsons, W.Va.: McClain, 1974), 525-30. 
America from Sweden; and the Bunners originated in Germany. ${ }^{33}$ In addition, the census also enumerated eighty-one blacks of probable African origin. ${ }^{34}$

Most of the people who settled in western Virginia during the eighteenth century were already second or even third generation Americans who had been born or raised in New Jersey, eastern Penns ylvania, or Maryland. Smaller numbers came from New York, Delaware, and eastern Virginia. As the settlers moved west, seldom did they relocate to the trans-Allegheny frontier in a single move. It was far more common to make the trip in a series of shorter moves as the frontier was pushed westward. Most settlers reached western Virginia by following the Great Wagon Road from eastern Pennsylvania southwest into the Shenandoah Valley of Virginia. From there, they followed old Indian trails and crude paths such as Braddock's Road across the Allegheny Mountains into western Virginia. ${ }^{35}$

Considering that so many trans-Allegheny settlers had at one time lived in or near southeastern Pennsylvania, it would be useful to briefly consider the domestic economy of rural Pennsylvanians to provide insight into the economic background of the settlers. The majority of Pennsylvanians during the second half of the eighteenth century were farmers who practiced diversified agriculture. The four most important grains raised on their farms included wheat, rye, oats, and maize (corn). Of the four, wheat, by far, was the most frequently cultivated. Not only was it a staple of the farmers' diet, but it was also their single most important marke table commodity. Rye, on the other hand, was of secondary importance. On the average, farmers cultivated only about 25 percent as much rye as wheat. Although some farmers had their rye ground into flour, Scots-Irish and Germans often distilled it into whiskey. Oats and corn, on the other hand, saw primary usage as animal feed. Some farmers also raised barley although typically

${ }^{33}$ Louise Sinclair, ed., "The John Dragoo Story," in The Dragoo Family News, no. 3, (September 1989): 12; Jerry Cunningham Collection, "The Springer Family," Handley Library Archives, Winchester, Virginia; William Bunner, personal conversation with author, 6 March 2000 .

${ }^{34}$ Core, Pioneers, 177.

${ }^{35}$ Rice, Allegheny, 65; Hu Maxwell, The History of Randolph County, West Virginia (1898; reprint, Parsons, W.Va.: McClain, 1991), 177-78. 
only in small quantities. Most people looked down on buckwheat as a "poor man's food," though many farmers planted it as a green manure. ${ }^{36}$

In addition to grains, most Pennsylvania farmers also raised a variety of fruits and vegetables. They adopted some species from the Indians including pumpkins, squash, and beans. Other vegetables grown on Pennsylvania farms came from Europe including peas, cucumbers, radishes, cabbages, carrots, spinach, and parsnips. They also grew potatoes and turnips not only for human consumption, but also as feed for farm animals. Common fruit trees included apples, peaches, and cherries. In addition to consuming their fruit fresh, farmers also dried some for future use and converted the rest into cider or brandy. Pigs consumed any fruit not suitable for human use. ${ }^{37}$

In addition to vegetable crops, almost every Pennsylvania farmer raised a variety of livestock including cattle, horses, sheep, and hogs. Of these, cattle were the most widely owned. Although few farmers possessed large herds, six or seven head was fairly typical. Even widows, day laborers, and city residents often owned a cow to provide fresh milk. Despite the relative abundance of cattle in Pennsylvania, outside observers frequently commented on their small size and poor physical condition. To a great extent, this can be attributed to the haphazard care they received. Although some farmers stall-fed their cattle by the $1760 \mathrm{~s}$, most allowed them to free range feeding on wild grasses and leaves. In addition, free range cattle mated randomly thus making it impossible for farmers to practice selective breeding. ${ }^{38}$

Pennsylvania farmers also rais ed large numbers of free range hogs. By slitting the ir ears in a distinctive manner, farmers could identify their own animals during fall round ups. By far, pork constituted the most important meat in the Pennsylvania diet. In fact, the average farm family consumed approximately twice as much pork as beef. Although many hogs averaged only about

\footnotetext{
${ }^{36}$ James T. Lemon, The Best Poor Man's Country: A Geographical Study of Early Southeastern Pennsylvania (Baltimore: Johns Hopkins Press, 1972), 151-57.

${ }^{37}$ Lemon, Best, 158; Dorothy Hartley, Lost Country Life (New York: Pantheon Books, 1979), 346; Sarah F. McMahon, "A Comfortable Subsistence: The Changing Composition of Diet in Rural New England, 1620-1840," William and Mary Quarterly, 3d ser., 42 (1985): 39-41.

${ }^{38}$ Lemon, Best, 161-64.
} 
175 pounds at the time of slaughter, farmers compensated for their small size by keeping anywhere from five to ten animals. On occasion, some farmers maintained upwards of thirty animals, ho wever this was unusual. ${ }^{39}$

Although most Pennsylvania farmers raised a surplus of produce and livestock, very few lived an entirely self-reliant existence. After all, people need more than ju st food to enjoy a competency. They also require shelter, clothing, tools, luxury items, and professional services. In many inst ances, farmers simply lacked the ability to produce a necessary item either at all or in sufficient quantities. A case in point is textiles. Despite having an agrarian-based economy, Pennsylvania farmers did not produce eno ugh wool or flax to supply all of their domestic textile needs. An analysis of household inventories from the second half of the eighteenth century reveals that abo ut 50 percent of Pennsylvania households owned no sheep, 60 percent had no flax, and 80 percent possessed no wool or yarn. In addition, many hou seho lds also lacked the tools necessary to process fiber into cloth. Approximately 30 percent of hou seholds had no spinning wheels and at least 90 percent lacked a lo om. To compensate for their inability to meet their domestic textile requirements, Pennsylvanians purchased large quantities of cloth imported from the British Isles. In other words, they depended on the commercial market to achieve a competency. ${ }^{40}$

Late eighteenth century Pennsylvania farmers did not live in a barter economy. They needed cash to purchase imported goods, and to obtain this cash, most farmers raised surplus agricultural products to sell locally and abroad. England and the West Indies received ship loads of flour, wheat, corn, flaxseed, salted beef, and lumber from rural Pennsylvania producers. In 1772 a lone, about L800,000 sterling worth of exports left Philadelphia ports. About 50 percent of this total came from the sale of wheat and flour. In addition to wheat products, about seven thou sand barrels of salted beef left Pennsylvania ports each year. In short, only by supplementing

\footnotetext{
${ }^{39}$ Ibid., 165-66.
}

${ }^{40}$ Adrienne D. Hood, "The Material World of Cloth: Production and Use in EighteenthCentury Rural Pennsylvania," William and Mary Quarterly, 3d ser., 53 (1996): 52-53; Lemon, Best, 27. 
their household production with commercially produced goods did rural Pennsylvania farmers achieve a compet ency. ${ }^{41}$

When Pennsylvania farmers moved to the we stern Virginia fro ntier, many of them found it difficult to attain the same levels of competency they had known in the East. A primary reason for this was their lack of easy access to the consumer goods available in stores a hundred miles away in the Shenandoah Valley. Unlike in eastern Pennsylvania, the settlers in trans-Allegheny Virginia found it difficult to supplement their household production with commercially produced goods. When the settlers moved to the western frontier, they left behind retail stores, craftmen's shops, county fairs, and weekly markets. With few exceptions, frontier communities in western Virg inia lacked local retail ou tlets during the first several years of settlement. In the middle Greenbrier Valley, for example, settlers who arrived in the late 1760s had to wait till 1771 before Sampson and George Mathews established a local trading post. ${ }^{42}$ Settlers in the upper Monongahela Valley in many cases had to wait even longer before receiving their first local store in $1783 .{ }^{43}$ In fact, dozens of pioneer families such as the Pricketts, Morgans, Coons, Ices, and Lowthers had lived in the Monongahela area for over a decade without having convenient access to a store. ${ }^{44}$

During the interval between initial settlement and the establishment of local stores, many pioneer families looked toward the older commercial centers of the Shenandoah Valley as a place to obtain those tools and supplies that could not be purchased locally. ${ }^{45}$ Towns such as Winchester and Staunton offered practically every material object a trans-Allegheny settler might require. For example, guns, axes, crosscut saws, saddles, salt, clothing, nails, and black powder

\footnotetext{
${ }^{41}$ Lemon, Best, 27-28, 181; Hood, "Material," 50.

${ }^{42}$ Frances Alderson Swope, comp., "The Matthews Trading Post Ledger, 1771-1779," Journal of the Greenbrier Historical Society 4 (1984), 20.

${ }^{43}$ Core, Pioneers, 98.

${ }^{44}$ Earl L. Core, Prelude, vol. 1 of The Monongalia Story: A Bicentennial History
} (Parsons, W.Va.: McClain, 1974), 197-220.

${ }^{45}$ Doddridge, Notes, 96-97. 
were all readily available in Winchester. If desired, farmers could also purchase breeding livestock, such as cattle, hogs, and horses. Ambitious settlers could even buy hives of honeybees. ${ }^{46}$ This access to the older commercial centers in the Shenandoah Valley allowed the settlers of western Virginia to avoid being cast into complete self-sufficiency.

By no means, however, was a "shopping trip" to the Shenandoah Valley an easy undertaking. Interposed between the western settlements and the Shenandoah Valley were the Allegheny Mountains, a twenty mile or more wide series of high parallel mountain ridges generally oriented in a northeast to southwest direction. With many individual peaks reaching over four thousand feet in elevation and only two partial river passes, crossing the mountains was an arduous endeavor. ${ }^{47}$ The journals and letters of eighteenth century travellers are filled with accounts of the hardships involved in crossing the mountains. In the summer of 1790 , for example, Methodist circuit rider Richard Whatcoat crossed the mountains on "As Ruf a Road" as he had ever encountered. ${ }^{48}$ Other writers lamented the mountain's steep slopes, downed trees, creeks, rivers, dangerous fords, mud, po orly blazed trails, absence of inns, deep mountain snows, and the "danger of being plucked off our horses by the boughs of the trees under which we had to ride." ${ }^{\prime 49}$ Perhaps traveller Samuel Allen said it best when he summarized his experiences in the mountains as simply "most horrid."

The ruggedness and poor condition of the trails through the mountains precluded the use of farm or freight wagons till after the Revolutionary War when some trails were upgraded to wagon roads. ${ }^{51}$ Prior to these improvements, settlers desiring supplies from the east either had to

${ }^{46}$ Frederic Morton, The Story of Winchester in Virginia: The Oldest Town in the Shenandoah Valley (Strasburg, Va.: Shenandoah Publishing House, 1925), 56-59.

${ }^{47}$ Oscar Doane Lambert, West Virginia and Its Government (Boston: D.C. Heath, 1951), 5; Rice, Allegheny, 4.

${ }^{48}$ Quoted in Core, Pioneers, 183.

${ }^{49}$ Quote from Francis Asbury, The Journal: 1771 to 1793, vol. 1 of The Journal Letters of Francis Asbury, (London: Epworth Press, 1958), 546.

${ }^{50}$ Quoted in Core, Pioneers, 249.

${ }^{51}$ Ibid., 236-37. 
walk or take pack horses over the mountains. Not surprisingly, trips to the Shenandoah Valley tended to be infrequent due to the difficulty of the journey. Settlers generally went east for supplies only once a year; usually in the late summer or fall. Settler David Crouch who grew up along the Tygart Valley River recalled how once a year his father would send a horse to the South Branch of the Potomac River to trade for salt. ${ }^{52}$ On a trip to western Virginia in September 1784, George Washington encountered "numbers of Pers ons and Pack horses going" east to obta in "Salt and other articles at the markets" of Maryland and eastern Virginia. ${ }^{53}$

Rather than each individual family making the difficult trip, neighbors frequently assembled their pack horse s into a single cara van to be lead by a master driver with a few young assistants. ${ }^{54}$ Caravans averaged about ten to fifteen horses each capable of carrying two hundred pounds of freight. ${ }^{55}$ An advantage of using caravans is that it allowed the settlers to obtain necessary supplies while at the same time leaving sufficient numbers of men behind to guard against possible Indian attacks. Through the use of annual pack trains, the settlers maintained a tenuous link with the external commercial market.

With commercially produced goods not always readily available, the first settlers, out of necessity, shifted the focus of the ir household production toward the subsistence end of the continuum. When necessary, they could sustain a very basic level of competency from the natural resources at hand. Consider, for example, the need for shelter. A shortage of local saw mills made it difficult for the first set tlers to construct the wooden-framed homes typical of cismontane farms. ${ }^{56}$ Although field stone was readily available in much of western Virginia, its exce ssive

\footnotetext{
${ }^{52}$ Elizabeth A. Perkins, Border Life: Experience and Memory in the Revolutionary Ohio Valley (Chapel Hill: University of north Carolina Press, 1998), 53.

${ }^{53}$ Quoted in Core, Pioneers, 113.

${ }^{54}$ Doddridge, Notes, 96-97.

${ }^{55}$ Core, Pioneers, 234.

${ }^{56}$ Rhys Isaac, The Transformation of Virginia, 1740-1790 (New Y ork: W. W. Norton, 1982), 33. If a settler had access to a whip saw or pit saw, he could produce about one hundred linear feet of boards per day; however, the work tended to be quite arduous. See John Morgan, "Log House Construction in Blount County, East Tennessee, " in Appalachian
} 
weight and high cost in terms of time and labor tended to discourage its use as a building material. ${ }^{57}$ In addition, few settlers would have possessed sufficient masonry skills to construct something as elaborate as a stone house even if they had wanted to.

Not surpr isingly, most settlers in trans-Allegheny Virginia favored hewn logs as a building material not only because they were cheap, but also because they were easy to manufacture. Although cabins tended to be small, it still required time for a family to cut the necessary number of trees, skid them to the construction site, and raise the cabin walls. While doing this preliminary work, new families on the frontier often lived in crude temporary structures. One family, for example, spent an entire summer living in a hut formed by leaning pine boughs against the face of a cliff. ${ }^{58}$ A few creative settlers found temporary shelter within the trunks of large standing hollow trees. ${ }^{59}$ Other families found temporary shelter in caves or rock overhangs. More typical, however, was for a family to build a half-faced shelter. This type of shelter usually appeared as a large wooden lean-to with an open front, earth floor, and either animal hides, blankets, or sheets of tree bark for a roof. On the ground directly in front of the open face was a large fire pit that could be used for heating and cooking. During particularly inclement weather, a blanket or animal skins could be hung across the open front to provide additional protection against wind or rain. Although there are a few documented instances of settlers dwelling in a half-faced shelter throughout the winter months, they were most frequently used only for short periods during the summer while construction of the permanent log cabin occurred. ${ }^{60}$

Frontiers: Settlement, Society, and Development in the Preindustrial Era, ed. Robert D. Mitchell (Lexington: University Press of Kentucky, 1990), 212-13. 148.

${ }^{57}$ Charles McRaven, Building with Stone (Pownal, Vt.: Garden Way Publishing, 1989),

${ }^{58}$ J. E. Wright and Doris S. Corbett, Pioneer Life in Western Pennsylvania (Pittsburgh: University of Pittsburgh Press, 1940), 42.

${ }^{59}$ Henry Haymond, History of Harrison County West Virginia(Morgantown, W. Va.: Acme, 1910), 19; Rice, History, 17.

${ }^{60}$ Wright, Pioneer, 19. 
The first cabins built in western Virginia tended to be small structures which offered few amenities. Packed earth often served as the cabin floor. In lieu of window glass, families sometimes used rawhide or paper which had been greased to make it translucent. ${ }^{61}$ Some of the more austere cabins even lacked fireplaces and chimneys. ${ }^{62}$ In these cases, the occupants built their cooking and heating fires directly on the dirt floor in the middle of the cabin. Smoke escaped through a hole cut in the peak of the roof. Many homes lacked even a single piece of iron hardware. ${ }^{63}$ Woo den pegs called "trunnels" were used instead of nails and door hing es could be fabricated either from wo od or pieces of strap leather. Through the use of a few simple hand tools, the settlers could construct their first crude homes totally from the natural materials at hand.

Like their homes, the settlers could also manufacture their own clothing if necessary. Although commercially produced cloth and shoes were available in the Shenandoah Valley and at some trading posts in western Virginia, they cost money which was frequently in short supply on the frontier. Even when cash was available, it often had to be saved to pay property taxes. ${ }^{64}$ Many settlers had no option but to either do without a particular article of clothing or to manufacture it within the household.

There are many documented instances of the early settlers wearing either minimal amounts of clothing or badly worn clothes. Con sider the case of settler Ja cob Parkhurst who as a child lived along Ten Mile Creek in present Washington County Pennsylvania. He explained that growing up, his

common dress was tow linen or dressed deer skin, when we had clothes, but boys, such as I and my twin brother, till about eight or ten years of age, had to do with one long shirt a year, which came down to the calf of the legs. When they were worn out we had to go naked, or nearly so, till the next crop of flax was manufactured into linen.

${ }^{61}$ Ibid., 43.

${ }^{62}$ Meshach Browning, Forty-Four Years of the Life of a Hunter (Winston-Salem, N. C.: Winston Printing Company, 1942), 103.

${ }^{63}$ Doddridge, Notes, 94.

${ }^{64}$ Haymond, Harrison, 272. 
During the "hard winter" of 1780, Parkhurst explained that

the snow fell early ... but we had not our new shirts yet; therefore, the twin boys were nearly naked. I began to contrive for myself and accordingly I found a small deer skin ... . so I put strings to it, turned the hair side next to my belly and wore it as an apron. Then I was well prepared to face the winter winds, my feet and legs still naked, and my old shirt gone except for the collar and a few threads hanging around. ${ }^{65}$

Even adults on the western Virginia frontier at times wore only minimal amounts of clothing either because they simply did not have it, or they were preserving it from wear. This seems to have most often been the case in regard to footgear. In June 1794, for example, itinerant minister Henry Smith preached to a backwoods congregation near present Fairmont. Looking over his audience, Smith "saw one old man who had shoes on his feet" and one man "wore Indian moccasins." Everyone else was barefooted. ${ }^{66}$

Much, if not most, of the clothing seen in the backcountry settlements was manufactured in the home from raw materials either gathered from the forest or grown on the farm. Linen, wool, and leather comprised the three most important materials for clothing manufacture. Leather was always a vailable in the form of deer, elk, and bison hides. Although leather could be purchased from professional tanners, most settlers would have known how to produce finished leather at home either through vegetable tanning with oak or hemlock bark or through "Indian tanning" with the tannic acid naturally found in animal brains. Although leather britches, hunting shirts, and leggings were common, a major drawback to leather clothing was its tendency to act as a sponge when it got wet. In addition, leather clothes have comparatively little insulating properties thus rendering them of limited utility in cold weather. Due to these disadvantages, the settlers preferred their clothing to be manufactured from cloth. ${ }^{67}$

\footnotetext{
${ }^{65}$ Quoted in Core, Pioneers, 30, 54.

${ }^{66}$ Quoted in Ibid., 229-30.

${ }^{67}$ Bruce Schwaegel, "Brain Tanning Buckskin," in The Book of Buckskinning III, ed.
} William H. Scurlock (Texarkana, Tex.: Rebel Publishing, 1985), 82-83; Mark Odle, "Tools and Technique s of Bark Tanning," in The Book of Buckskinning VII, ed. William H. Scurlock (Texarkana, Tex.: Scurlck Publishing, 1995), 223-48. 
The two most important fabrics in the backcountry settlements were linen and wool. They could either be used separately or be woven together to produce linsey-woolsey. During the first year or two on the frontier, even these two mainstays of the frontier seamstress were not always available. Linen, for example, comes from the flax plant which must be planted in the spring of the year and be harvested on schedule some time in mid to late July. If harvested either too early or too late, the fibers located in the stalks will be unfit for use in clothing. Therefore, for a settler to raise a harvestable flax crop during his initial year on the frontier, he must have arrived early enough in the year to have had adequate time to clear sufficient land and get his crop in the ground early in the spring. Undoubtedly, some families arrived too late in the year to plant flax. In this case, they either did without, purchased commercial cloth, or looked to the surrounding forests for a suitable substitute. Resourceful families sometimes obtained useable fibers from the partially rotted stems of stinging nettle plants gathered in the late winter or early spring, though the quality was not as good as flax. ${ }^{68}$

Next to linen, wool was the most commonly used fiber in the home production of cloth in western Virginia. Due to its thermal qualities, it had particular value in the manufacture of cold weather clothing such as stockings, thick petticoats, capotes, great coats, match coats, mittens, caps, and as liners for homemade shoe packs. In addition, when woven to gether with linen, it made comfortable cool weather clothing. ${ }^{69}$

It is impossible to determine the amount of wool available to the settlers of western Virginia. Local tax records did not enumerate sheep during the late eighteenth century and there are so few estate inventories available that statistical data derived from them has little meaning. Only in a few instances are there extant anecdotal references to sheep being present in western Virginia. Unfortunately, most of these references relate to them being killed by wild animals. Wolves were particularly destructive. For example, settler William Scripps of the Monongahela

\footnotetext{
${ }^{68}$ Judy Wilson, personal conversation with author, 10 June 1999.

${ }^{69}$ Ibid.
} 
Valley lost twenty sheep to wolves in 1794. This left his family with no wool with which to make winter clothing. ${ }^{70}$

Like stinging nettle, wool substitutes could be found in the surrounding forests. Imaginative settlers sometimes visited "buffalo wallows" in the spring of the year to gather naturally shed buffalo wool. At other times, settlers harvested wool from the hides of bison that had been shot. There are even some accounts of nettle and bison wool being woven together to make a linsey-wo olsey substitute. Unfortunately, other than a few first hand accounts of this being done, there is no way of determining the extent of this practice. Regardless of its extent, the important point is that the settlers could and did provide themselves with clothing when commercially produced cloth and clothes were not available or convenient. ${ }^{71}$

The diet of the initial settlers, like their homes, also tended to be very basic. ${ }^{72}$ Even though most settlers were farmers, it took time to develop a homestead to a point where it could provide a family with adequate food. ${ }^{73}$ Settler John Scripps recalled that during the first few years on the frontier, "few settlers had land in cultivation more than sufficient to raise food for their own consumption, and generally by Spring there would be no bread in the country and people lived on [wild] greens . . daily gathered by women and children."74 Joseph Doddridge also recalled having to "live without bread" for six weeks in 1773 when his family ran out of grain. They subsisted by eating venison, wild turkey, and bear meat, although "after living in this way for some time," the family "became sickly" and was "tormented with a sense of hunger."75 Jacob Parkhurst similarly described how his family hunted wild game to augment the limited quantities

${ }^{70}$ Haymond, Harrison, 272.

${ }^{71}$ Judy Wilson, personal conversation with author, 10 June 1999.

${ }^{72}$ Leland D. Baldwin, Whiskey Rebels: The Story of a Frontier Uprising (Pittsburgh: University of Pittsburgh Press, 1939), 4.

${ }^{73}$ Robert D. Mitchell, Commercialism and Frontier: Perspectives on the Early Shenandoah Valley (Charlottesville: University Press of Virginia, 1977), 3, 134.

${ }^{74}$ Haymond, Harrison, 272.

${ }^{75}$ Doddridge, Notes, 82. 
of corn, milk, and vegetables being produced on their family farm. ${ }^{76}$ Only by supplementing their meager farm products with wild game, nuts, and fruits were the initial set tlers able to survive during their first few years on the frontier.

Although the forest provided the settlers with food, it was also seen as an impediment to agriculture. The massive trees supported a thick leafy canopy that cast the land into deep shade during the summer months. Agriculture in such a dim environment was simply impossible. In response, the settlers adopted the slash and burn farming methods that had long been employed by the Delawares and other tribes of Eastern Woodland Indians. ${ }^{77}$ A late eighteenth century observer described how the settlers cleared their land:

The general mode of clearing the land in this country, where timber is of no value, and labour is great, is by cutting a circle round the tree, through the bark, quite to the wood, before the sap rises, which kills it; and they . . . [leave] the trees to rot standing, which happens within a very few years, and they never bear leaves more. $^{78}$

The settler could then dispose of the "deadenings" at his leisure. If a sufficient number of neighbors or family members lived close by, a "log-rolling" might be called in which communal work parties removed the underbrush and smaller dead wood, placed it in piles, and set it on fire. Stumps, roots, and the larger tree trunks were left in place with little adverse effect on future crop yields. $^{79}$

Once a plot had been cleared, settlers planted a wide variety of crops between the stumps and dead trees. Corn, potatoes, pumpkins, squash, beans, turnips, and other vegetables were staples of the pioneer diet. Sometimes, the settlers planted these crops in haphazard rows; other

${ }^{76}$ Quoted in Core, Pioneers, 30.

${ }^{77}$ J. S. Otto and N. E. Anderson, "Slash-and-Burn Cultivation in the Highlands South: A Problem in Comparative Agricultural History," Comparative Studies in Society and History 24 (January 1982): 136-37.

${ }^{78}$ J. F. D. Smyth, A Tour of the United States of America, vol. 1 (1774; reprint, New York: Arno Press, 1968), 94.

${ }^{79}$ Otto and Anderson, "Slash," 133. 
times, they planted Indian-style in thirty inch diameter hills of mounded earth. ${ }^{80}$ Although the settlers may not have realized it, planting in hills helped to reduce the danger of frosts by trapping the cold air close to the ground between the hills. ${ }^{81}$

After planting the same field for several successive years, erosion and soil exhaustion caused a marked decline in crop yields. A typical field could support a corn crop for anywhere from four to six years before loosing its fertility. ${ }^{82}$ A heavy feeder such as tobacco, on the other hand, exhausted the soil after only three years. ${ }^{83}$ Regardless of the crop, when a field became exhausted, the settlers turned it over to fallow pasture and moved on to a newly cleared field. Over time, saplings and brush invaded the fallow field eventually restoring it to forest. After spending twenty years minimum as new growth forest, the soil would recover enough fertility to merit reclearing. For est fallowing required such a long period of time that seldom did a single person witness an entire cycle. ${ }^{84}$

Forest farming offered a number of attractions to Appalachian farmers. For one thing, deadenings generated air currents that promoted the generation of dews and fogs that served as protection from unseasonal frosts. Another advantage of farming within deadenings is that the standing dead trees reduced the loss of moisture in plants by breaking up surface winds.

Furthermore, burning brush not only helped to kill weeds and insect pests on the ground, but it also helped to enrich the soil by providing it with potassium and other minerals found in wood ashes. Perhaps most important to the pioneers was the fact that girdling trees and burning brush was far less labor intensive than felling every last tree and grubbing out their massive stumps.

${ }^{80}$ Conrad E. Heidenreich, "Huron," in Northeast, vol. 15, Handbook of North American Indians (Washington, D.C.: Smithsonian Institution, 1978), 381.

${ }^{81}$ Bruce G. Trigger, The Huron: Farmers of the North, 2d ed. (Fort worth: Harcourt Brace Jovanovich College Publishers, 1990), 33.

${ }^{82}$ Ibid., 31.

${ }^{83}$ Allan Kulikoff, Tobacco and Slaves: The Development of Southern Cultures in the Chesapeake, 1680-1800 (Chapel Hill: University of North Carolina Press, 1986), 47.

${ }^{84}$ John Fraser Hart, "Land Rotation in Appalachia," Geographical Review 67 (1977): 151; Kulikoff, Tobacco, 47. 
Considering that many backcountry families relied solely on their own labor, this last consideration becomes particularly significant. ${ }^{85}$

Another laborsaving tactic of backcountry settlers involved the open-range herding of cattle and hogs similar to what had been practiced in eastern Pennsylvania. Open-range livestock needed far less care than a nimals kept in stables and fed grain or hay. One disadvant age, though, was that free range husbandry required ext ensive tracts of woodland where the animals could graze on wild grasses, leaves, and mast. Considering that few settlers posses sed title to sufficient land to practice this system on their own property, they often fenced in their own grain fields and gardens leaving everyplace else, including the land of neighbors and absentee land owners, open for grazing. Hogs tended to thrive in the wo odlands. Cattle, on the other hand, did less well because of the sparseness of grass in the dim forests. Some farmers rectified this problem by setting fire to the forest floor in the late winter to promote the growth of springtime grasses. ${ }^{86}$

By examining the basic lifestyle of the pioneers of western Virginia, it becomes evident that subsistence modes of production played a major role in their pursuit of competency; much more so than it did when they had lived in eastern Pennsylvania. To an extent, the settlers' heavy reliance on subsistence production can be explained by their physical remoteness from the established commercial centers of the east. By no means, however, does iso lation tell the whole story. After all, the settlers of other Virginia frontiers, such as the Shenandoah Valley, had also experienced physical remoteness from established commercial markets. In the Valley, this initial period of "marginal living standards" lasted for only "the first year or two of initial permanent settlement." ${ }^{17}$ In west ern Virginia, however, many set tlers struggled for over a decade to achieve a competency. What then was the difference? One major distinction between the two frontiers

\footnotetext{
${ }^{85}$ Otto and Anderson, "Slash," 141-42; Peter Nabokov and Dean Snow, "Farmers of the Woodlands," in America in 1492: The World of the Indian Peoples before the Arrival of Columbus, ed. Alvin M. Josephy, Jr. (New York: Alfred A. Knopf, 1993), 127.

${ }^{86}$ Otto and Anderson, "Slash," 137; Ronald L. Lewis, Transforming the Appalachian Countryside: Railroads, Deforestation, and Social Change in West Virginia, 1880-1920 (Chapel Hill: University of North Carolina Press, 1998), 27; Smyth, Tour, 95-96.

${ }^{87}$ Mitchell, Commercialism, 3.
} 
was the proximity of hostile Indian tribes. The Shenandoah Valley had largely been emptied of its native inhabitants by the time settlers began arriving in the $1730 \mathrm{~s} .{ }^{88}$ Settlers in western Virginia, on the other hand, faced a powerful confederacy of Indian tribes determined to retain possession of their land and resources. The next chapter explores the negative impact that twenty years of warfare (1774-1794) had on the domestic economy of both the settlers and the native inhabitants of the upper Ohio Valley.

${ }^{88}$ See Barber, "Native," 134-58. 
Chapter Three:

Competency and War

On a rainy day in June 1919, two hundred people gathered near the mouth of Pricketts Creek in the Monongahela Valley to attend the dedication of a monument marking "the site of Prickett's Fort built in 1774 on the land of Jacob Prickett." The keynote speaker for the occasion was Judge James R. Moreland, the state president of the Sons of the Revolution. In a patriotic speech, he honored the memories of those men and women who had played a role in the settlement of the Monongahela Valley frontier. What he failed to stress, however, was that the region had already been settled thousands of years prior to the arrival of any European families. ${ }^{1}$

Mor eland's oversight is of little surprise. American writers and speakers have regularly relegated Indians to a secondary role in frontier narratives, often treating them as little more than adversaries, or "props," in one-sided celebrations of pioneer heroics. ${ }^{2}$ Although it is true that many Indians did become mortal adversaries of the trans-Allegheny settlers, it would do the Indians yet one more injustice if this chapter were to launch directly into an analysis of the "negative economic impact" they had on white settlers without first introducing the Indians as a people with identities independent of white frontiersmen. Only by first understand ing who the Indians were and how they achieved their own livelihood can the Indian war of 1774 to 1794 be fully appreciated as an economic war fought to determine which race would control the finite land and resources of western Virginia.

The Indian tribe most often asso ciated with the western Virginia frontier has been the Shawnees. Although all Shawnees spoke the same language and shared a common culture, their tribal political structure was very de-centralized with most political power residing within the

\footnotetext{
1"Historical Monument Erected by Sons of the Revolution Dedicated with Appropriate Ceremonies," The Fairmont Times, 27 June 1919. The monument can still be seen at Prickett's Fort State Park near Fairmont, West Virginia.

${ }^{2}$ Michael J. Puglisi, "Introduction," in Diversity and Accommodation: Essays on the Cultural Composition of the Virginia Frontier ed. Michael J. Puglisi (Knoxville: University of Tennessee Press, 1997), 6.
} 
various villages. Ranging in size from a few dozen people to over a thousand inhabitants, Shawnee villages were governed by a system of civil chiefs, war chiefs, and village councils. Although most decisions regarding daily life were made on the village level, matters of major importance, such as warfare and diplomacy, were addressed in a national council under the leadership of a tribal chief. Thus, even though the Shawnees had a very loose political structure, when necessary they could present a united front. ${ }^{3}$

Within Shawnee society there existed a well-defined division of labor based up on one's sex. Children grew to adulthood with a clear understanding of their future role in family and village life. ${ }^{4}$ Shawnee men focused their labor activities on hunting, trapping, fishing, and warfare while women attended to domestic matters such as farming, child rearing, tanning leather, wigwam construction, and cooking. Such a pronounced division of labor existed because hunting and warfare often removed men from a village for an extended period of time. With the men frequently gone, virtually all domestic duties fell to the women. ${ }^{5}$ Occasionally, men helped with the more physically demanding chores such as clearing a new garden plot in the forest, however, once the ground was ready for planting, his involvement with agriculture typically ended. ${ }^{6}$ Although the different sexes labored at very different tasks, together, they provided effectively for the needs of their village and families.

The Shawnees derived their livelihoods through a combination of hunting, fishing, gathering, farming, and trading. The men hunted a variety of game animals including deer, elk,

${ }^{3}$ John Sugden, "Shawnee," in Encyclopedia of North American Indians, ed. Frederick E. Hoxie (Boston: Houghton Mifflin, 1996), 582; Jerry E. Clark, The Shawnee (Lexington: University Press of Kentucky, 1993), 31-33; James H. Howard, Shawnee!: The Ceremonialism of a Native American Indian Tribe and Its Cultural Background (Athens: Ohio University Press, 1981), 106-9; Paul A. W. Wallace, Indians in Pennsylvania, 2d ed. (Harrisburg: Pennsylvania Historical and Museum Commission, 1993), 119-20. On the informal political power of women in tribal politics, see Anthony F. C. Wallace, The Death and Rebirth of the Seneca (New York: Vintage Books, 1969), 29.

${ }^{4}$ James Axtell, ed., The Indian Peoples of Eastern America: A Documentary History of the Sexes (New York: Oxford University Press, 1981), 103.

${ }^{5}$ Wallace, Death, 28-29; Axtell, Indian, 103.

${ }^{6}$ Clark, Shawnee, 31. 
bear, raccoons, turkeys, and to a lesser extent, beavers, squirrels, and other small game animals. ${ }^{7}$ By far, the single most important so urce of animal protein was the white-tailed de er which the men hunted in all seasons. Archeologists studying bone fragments from the site of a seventeenth century village in present Putnam County estimated that $89 \%$ of the inhabitants' meat came from deer. The researchers further determined that for every one hundred deer that were killed, the Indians harvested only thirteen raccoons, eight squirrels, four turkeys, and two beavers. Somewhat surprising was a total absence of buffalo remains. Considering the large size of these animals, the hunters may have butchered them at the kill site. ${ }^{8}$

Shawnee men also contribut ed to the subsistence of their families by fishing and gathering fresh water clams. Unlike hunting which occurred year round, fishing tended to coincide with the spring spawning runs. ${ }^{9}$ The men used several different methods of fishing including angling with bird claw fishhooks and bo ne gorges, netting, spearing by torchlight, shooting with bow and arrows, and wicker traps. ${ }^{10}$ In addition, fish could be poisoned by pouring a prepared mixture of ground buckeye nuts and special roots into a pool of water. The poison temporarily stunned the fish causing them to float to the surface where waiting fishermen quickly gathered them into baskets. $^{11}$

The Shawnees added seasonal variety to their diet by gathering wild plant foods from the forest. As a general rule, they consumed wild fruits and berries fresh, though on occasion, they

${ }^{7}$ James B. Griffin, "Late Prehistory of the Ohio Valley," in Northeast, vol. 15, Handbook of North American Indians (Washington, D.C.: Smithsonian Institution, 1978), 552.

${ }^{8}$ John E. Guilday, Biological and Archeological Analysis of Bones from a 17th Century Indian Village (46 PU 31), Putnam County, West Virginia (Morgantown: West Virginia Geological and Economic Survey, 1971), 7, 21-22, 34.

${ }^{9}$ Ibid., 40.

${ }^{10}$ Clark, Shawnee 40; Wallace, Indians, 37.

${ }^{11}$ Daniel L. Boxberger, "Fishing," in Encyclopedia of North American Indians, ed. Frederick E. Hoxie (Boston: Houghton Mifflin, 1996), 199; Axtell, Indian, 131. 
dried some for future use. ${ }^{12}$ Chestnuts, hickory nuts, and acorns were also stored for the future. ${ }^{13}$ In the late winter, the Shawnees produced sugar by tapping maple trees and boiling down the sap over a slow fire. A single tree could yield up to seven pounds of sugar each spring. Like other forms of gathering, sugaring was considered the work of women and children, though men sometimes helped if the winter hunt had been completed. ${ }^{14}$ In light of the fact that honeybees had just recently been introduced to North America, maple sugar was the Shawnees' traditional source of sweetener. ${ }^{15}$

The Shawnees practiced slash and burn agriculture in much the same fashion as white Appalachian settlers. Originally, they had used stone hatchets to clear away undergrowth and to girdle any larger trees loc ated within the bounds of their pro spective fields. Later, iron to ols obtained from English or Indian traders made the work much easier. Considering that one acre of old growth forest contained an average of twenty-six trees with trunk diameters over eighteen inches, iron axes quickly became a popular trade item. ${ }^{16}$ After the cut wood had dried, the Shawnees piled it around the girdled trunks of the larger trees and set it all ablaze. Women gradually grubbed out the smaller stumps leaving the larger stumps and trunks in place. In all, it often required several years to prepare a new field for planting. ${ }^{17}$

The Shawnees raised their crops in small hills rather than rows. Using hoes fashioned from the shoulder blades of deer, the women scraped the topsoil into mounds that measured about ${ }^{12}$ Thomas Wjidcat Alford, Civilization: As Told to Florence Drake (Norman: University
of Oklahoma Press, 1936), 41 .

${ }^{13}$ Alvin M. Josephy, Jr., America in 1492: The World of the Indian Peoples before the Arrival of Columbus (New York: Alfred A. Knopf, 1993), 128.

${ }^{14}$ Axtell, Indian, 127-28.

${ }^{15}$ Alfred W. Crosby, Ecological Imperialism: The Biological Expansion of Europe, 9001900 (Cambridge: Cambridge University Press, 1986), 188-89.

${ }^{16}$ Stanley W. Baker, "An Iron Trade Axe from the Neale's Landing Site, 46WD39, on Blennerhassett Island," West Virginia Archeologist 36 (1988); Guilday, Biological, 4.

${ }^{17}$ Bruce G. Trigger, The Huron: Farmers of the North, 2d ed. (Fort Worth: Harcourt Brace Jovanovich College Publishers, 1990), 31. 
thirty inches in diameter with an additional thirty inch space between the mounds. ${ }^{18}$ Land that had been to tally cleared of all trees and stumps had space sufficient for approximately twenty-five hundred hills per acre. ${ }^{19}$ Into each hill was planted a combination of corn, beans, and squash. Whether they also raised tobacco (Nicotiana rustica) like their neighboring tribes to the north and east is unknown. ${ }^{20}$ By planting corn a few weeks prior to beans and squash, the cornstalk would serve as a living bean pole. ${ }^{21}$ Throughout the summer, women periodically hoed the field to keep weeds down. Even young children contributed to the family's subsistence by guarding the field against birds and animals.

Barring drought, blight, insects, and animal pests, the villagers could expect to harvest the ir first roasting ears about eighty-four days after planting. To celebrate the occasion, they held their annual Green Corn ceremony in mid-August. Two weeks later, the longer season varieties ripened. $^{22}$ For winter storage, the women peeled the husks back from the corn cobs without breaking them off and braided them together into long strands that were suspended from the interior roof of a wigwam. ${ }^{23}$ If de sired, the dried kernels could later be shelled and st ored in baskets or clay pots. In addition, the wo men preserved squash and pumpkins for up to five months by drying thinly sliced pieces. ${ }^{24}$

Calculating the Shawnees' agricultural pro ductivity during the eighteenth century is difficult due to a scarcity of documentation on the subject. A tentative answer to this question,

${ }^{18}$ Ibid., 32.

${ }^{19}$ Conrad E. Heidenreich, "Huron," in Northeast, vol. 15, Handbook of North American Indians (Washington, D.C.: Smithsonian Institution, 1978), 380.

${ }^{20}$ Robert F. Maslowski, Prehistoric People of the Kanawha Valley, $<$ http://www.wvlc.wvnet.edu/wvarl/srbk.html.html>, 13 September 1997; Clark, Shawnee, 40.

${ }^{21}$ Howard, Shawnee!, 49.

${ }^{22}$ R. Douglas Hurt, Indian Agriculture in America: Prehistory to Present (Lawrence: University Press of Kansas, 1987), 31; Howard, Shawnee!, 269.

${ }^{23}$ Alford, Civilization, 35.

${ }^{24}$ Trigger, Huron, 33. 
however, can be gained by examining the known corn yields of other agriculturalists in the region. During the late seventeenth century, a French Jesuit observed that the Hurons achieved average yields of twenty-seven bushels of corn per acre. Anthropologist Conrad Heidenreich concurred with the Jesuit's observations, but also noted that the Hurons' yields sometimes dropped to as low as seven to ten bushels per acre when the soil had become exhausted. White settlers using similar slash and burn methods also achieved harvests of between twenty to thirty bushels per acre of hills. ${ }^{25}$ Based on the above observations, it is reasonable to assume that the Shawnees achieved similar results.

Although agriculture was important to the Shawnees, they did not depend on it as heavily as other Eastern Woodland tribes. This becomes evident when one considers that a Shawnee family of five to eight people typically cultivated only about one acre of crops for the entire family whereas other related tribes planted one acre per person. Anthropologists who have studied Shawnee agriculture conclude that "clearly corn was not a staple food in the year-round subsistence economy of the Shawnee; for half of each year, at least, it figured only minimally, if at all in their basic economy." ${ }^{12}$ Understanding that the Shawnees were less dependent on horticulture than many of their neighboring tribes helps to explain why American frontiersmen had such a difficult time dislodging them from the upper Ohio Valley despite having burnt their crops on an almost annual basis. ${ }^{27}$ Although farming was important to the Shawnees' subsistence, hunting was even more so.

\footnotetext{
${ }^{25}$ Heidenreich, "Huron," 381.
}

${ }^{26}$ Erminie Wheeler Voegelin, "The Place of Agriculture in the Subsistence Economy of the Shawnee," Papers of the Michigan Academy of Science, Arts, and Letters 26 (1940): 518-20; Clark, Shawnee, 41.

${ }^{27}$ For an overview of American efforts to dislodge the Shawnees from the upper Ohio Valley, see Randolph C. Downes, Council Fires on the Upper Ohio: A Narrative of Indian Affairs in the Upper Ohio Valley until 1795 (Pittsburgh: University of Pittsburgh Press, 1968). For more popular, yet historically accurate, accounts of the same topic, see James Alexander Thom, Panther in the Sky (New York: Ballantine Books, 1989), and Allan W. Eckert, The Frontiersmen: A Narrative (New York: Bantam Books, 1967). 
Through their combination of hunting, fishing, gathering, and horticulture, the Shawnees provided for all of their basic needs. But like most Europeans, mere subsistence was not entirely satisfying. The Shawnees, therefore, augmented their household subsistence by trading with neighbors for luxury items not locally available. ${ }^{28}$ Prior to the arrival of Europeans, the Shawnees engaged in extensive intertribal trade over a sophisticated network of well-used trails that connected western Virginia with locations as widespread as the Atlantic and Gulf Coasts, the lower Ohio Valley, and Canada. ${ }^{29}$ Desired trade goods included marine shells, unusual varieties of stone, and cold-hammered copper. From these materials, the Shawnees fashioned jewelry items such as conch shell gorgets, green steatite smoking pipes, and strings of beads made from tiny sea shells. ${ }^{30}$

Little information exists regarding commodities that the Shawnees may have exchanged in return, though some scholars suspect that chert and canel coal were two. ${ }^{31}$ Other researchers suggest that they may have been salt traders. It is known that the Shawnees sometimes visited natural salt springs where they collected the briny wat er in clay pans and allowed it to naturally evaporate leaving behind a thin layer of salt crystals. ${ }^{32}$ In the summer of 1755 , white captive Mary Draper Ingles helped a party of Shawnees make salt in the Kanawha Valley of western Virginia. ${ }^{33}$ While some of this salt was used for domestic purposes, any surplus would have been available for barter.

\footnotetext{
${ }^{28}$ Daniel Vickers, "Competency and Competition: Economic Culture in Early America," William and Mary Quarterly, 3d ser. 47 (1990): 3; Timothy G. Baugh and Jonathan E. Ericson, eds., Prehistoric Exchange Systems in North America (New York: Plenum Press, 1994), 420.

${ }^{29}$ Ibid., 35, 41; Edward V. McMichael, Introduction to West Virginia Archeology, 2d ed., rev. (Morgantown: West Virginia Geological and Economic Survey, 1968), 51; Josephy, America, 128-29.

${ }^{30}$ Ronald W. Moxley, "The Orchard Site: A Proto-Historic Fort Ancient Site in Mason County, West Virginia," West Virginia Archeologist 40 (Spring 1988): 35, 38-40.

${ }^{31}$ Baugh, Prehistoric, 232.

${ }^{32}$ Clark, Shawnee, 32, 41.

${ }^{33}$ John P. Hale, Trans-Allegheny Pioneers, 3d ed. (Radford, Va.: Roberta Ingles Steele, 1971), 38.
} 
The Shawnees carried out their various subsistence activities in an annual cycle based upon the seasons. Throughout the fall from late September through December, they generally lived in small temporary hunting camps scattered throughout, Ohio, Kentucky, and western Virginia. Leaving the elders, children, and some of the women behind at these camps, the men spread out over the countryside to hunt deer, bears, and other animals. Sometime around January, the men shifted their attention away from deer hunting in favor of trapping fur bearers such as beavers. Trapping typically continued till late February when the hunting camps broke up and everyone returned to their towns located mostly in eas tern and central Ohio. Springtime activities included maple sugaring and preparing fields for planting. Throughout the summer, the women tended their crops while the men hunted or waged war against enemies near and far. By the end of harvest in September, the Shawnees again divided into small extended family groups and moved to their winter quarters to start the cycle anew. ${ }^{34}$

By the early 1770 s, so many white families had moved to the forests of western Virginia that the Shawnees found it difficult to practice their seasonal movements. According to a Shawnee diplomat, the problem with settlers was two-fold. First, there was the issue of "the woods [being] covered with White people." ${ }^{135}$ By this, he implied that the mere physical presence of settlers was disruptive to his people's way of life. How could they move to their winter camps if settlers occupied their hunting grounds? Chiksika, brother of Tecumseh, eloquently expressed the frustration felt by many Shawnees when he proclaimed that "The whole white race is a monster who is always hungry and what he eats is land." ${ }^{36}$

\footnotetext{
${ }^{34}$ Clark, Shawnee, 38-41; Charles Callender, "Shawnee." in Northeast, vol. 15 of Handbook of North American Indians, edited by Bruce G. Trigger (Washington: Smithsonian Institution, 1978), 624; Roy Bird Cook, Washington's Western Lands (Strasburg, Va.: Shenandoah Publishing House, 1930), 33.

${ }^{35}$ Downes, Council, 154.

${ }^{36}$ Allan W. Eckert, A Sorrow in Our Heart: The Life of Tecumseh (New York: Bantam Books, 1992), iv.
} 
A second complaint lodged by the diplomat was that their young men were "disappointed in their hunting." ${ }^{137}$ As increasing numbers of pioneer families arrived in western Virginia, the Shawnees faced escalating competition for the finite game resources. Undoubtedly, the wasteful hunting practices of many settlers aggravated the situation. Consider William Haymond, Jr. of Harrison County who admitted that whenever he saw a deer, he simply could "not resist the temptation to shoot it."138 Further evidence of this attitude is reflected in the journal of explorer Christopher Gist who reported killing a dozen turkeys in a single day. ${ }^{39}$ Apparently, wasteful hunting practices were learned early. Following the Revolutionary War, traveller Johann David Schoepf reported that two boys near Wheeling had killed 219 squirrels over a three day period. ${ }^{40}$ After a generation of such wanton hunting practices, set tler Jo seph Doddridge lamented that "the buffalo and elk have entirely disappeared from this section of the country. Of the bear and deer but very few remain. ... . The wild turkeys, which used to be so abundant . . . are now rarely seen." ${ }^{11}$

The Shawnees realized that if they did nothing to stem the flow of settlers into western Virg inia, they sto od to lose not only tribal land, but also the ir very way of life. After all, their basic subsistence was based on having access to the deer, fish, wild plants, and farmland of the region; the very same resources needed by white settlers who lacked easy access to commercial goods. Herein lies the fundamental cause of the western Virginia Indian wars: the Shawnees and settlers both relied on the same resources to achieve their livelihoods. The stakes in this

${ }^{37}$ Downes, Council, 154.

${ }^{38}$ William Haymond, Jr. to Luther Haymond, 13 April 1842, William Haymond, Jr. Papers, West Virginia Regional and Hist ory Collection, West Virginia University.

${ }^{39}$ William M. Darlington, Christopher Gist's Journals with Historical, Geographical, and Ethnological Notes and Biographies of His Contemporaries (Pittsburgh: J. R. Weldin, 1893), 35.

${ }^{40}$ Johann David Schoepf, Travels in the Confederation, 1783-1784 vol. 1, ed. Alfred J. Morrison (New York: Burt Franklin, 1986), 295.

${ }^{41}$ Joseph Doddridge, Notes on the Settlement and Indian Wars (1912: reprint, Parsons, W. Va.: McClain, 1976), 57, 59. 
competition for resources were part icularly high considering that deprivation would likely result in destitution.

Early on, some form of accommodation might have been possible, however, by the summer of 1774, coexistence was no longer an option. If a single point of no return exist ed, it must have been on 30 April 1774, when Daniel Greathouse led an at tack against the village of the friendly Mingo chief, John Logan. Following that heinous event, the skirmishing and haras sment that had been going on for months escalated into a full-fledged war that would last intermittently from 1774 till 1794 when General Anthony Wayne dealt the Shawnees a demoralizing defeat at the Battle of Fallen Timbers.

Starting in 1774, the Shawne es began raiding into western Virginia with devastating effect. Over the ensuing two decades, hundreds of settlers lost their lives in count less batt les and ambushes. Considering the high level of destruction to life and property, the small size of most war parties is somewhat surprising. Typically, they ranged in size from about eight to fourteen warriors, although on occasion, the Shawnees attacked in bodies larger than twenty. Only four times during twenty years of fighting did the Indians attack western Virginia in numbers that can be considered an army. Excluding the Battle of Point Pleasant which involved upwards of a thousand Indians, the largest of these forces included only about three hundred warriors. ${ }^{42}$

What the Shawnees lacked in manpower, they made up for in tactics. They were masters of forest warfare. After silently infiltrating the settlements, they would set ambushes and wait for unwary settlers to pass. Favorite ambush sites included the areas around springs, corn fields, flax patches, and trails. Sometimes, war parties waited outside a cabin door and attacked the first person to step out in the morning. At other times, a group of warriors would rush an open cabin door trying to gain entrance before the occupants could get it closed. When not waiting in ambush, war parties scouted the settlements, burnt crops, killed livestock, and burglarized and burnt cabins. Frontier narratives such as Alexander Scott Withers' Chronicles of Border Warfare detail scores of such Indian attacks against the settlements of western Virginia. Additional

\footnotetext{
${ }^{42}$ Otis K. Rice, The Allegheny Frontier: West Virginia Beginnings, 1730-1830 (Lexington, University Press of Kentucky, 1970), 96, 102, 116.
} 
accounts are lodged within the various county court records, the Draper manuscripts, and the unpublished memoirs of the settlers themselves. Just a few representative examples will suffice to convey the type of destruction that occurred. On 16 April 1778, a war party "killed 7 sheep and skinned them and took 15 horses" in a raid near the mouth of the Cheat River. ${ }^{43}$ On another occasion, a settler by the last name of Johnson returned home from a hunting trip to discover that the Indians had at tacked his homestead. His cow and pig lay dead in the front yard and the interior of his cabin had been ransacked. Over a mile away, the scalped bodies of his wife and three children lay on the forest floor. ${ }^{44}$ Although there is no way of determining precisely how much total damage occurred to the settlers' persons and property, anecdotal accounts suggest that the destruction was considerable. In the face of such losses, attaining a competency became much more difficult for the settlers.

Aside from outright destruction to life and property, the Indian raids also hindered the economic development of the region by depopulating large areas of the frontier. When the war began in 1774, a "panic . . . seized the people" of the Monongahela and Ohio valleys. ${ }^{45}$ Within a few weeks, hundreds of frightened families had abandoned their homesteads fleeing eastward in such haste that in some cases they failed to take personal belongings and livestock with them. ${ }^{46}$ One Fayette County, Pennsylvania observer of the exodus wrote that "the country at this time is in great confusion. . . I suppose there have been broken up and gone off at least 500 families within one week past." ${ }^{47}$ That same year, 1774, the settlements around present Bridgeport "broke up

${ }^{43}$ Earl L. Core, The Pioneers, vol. 2 of The Monongalia story: A Bicentennial History (Parsons, W. Va.: McClain, 1976), 23-24.

${ }^{44}$ Haymond to Haymond, 25 March 1842.

${ }^{45} \mathrm{C} . \mathrm{W}$. Butterfield, The Washington-Crawford Letters Being the Correspondence between George Washington and William Crawford from 1767-1781 (Cincinnati: Robert Clarke, 1877), 51.

\footnotetext{
${ }^{46}$ Ibid., 89.

${ }^{47}$ Eckert, Sorrow, 836.
} 
and moved down to Prickets Settlement and Built a Fort" as protection against Indian attack. ${ }^{48}$ Five years later, the settlements along Hackers Creek in present Lewis County also broke up with some families "forsaking the country and retiring east of the mountains" while others moved into forts near present Buckhannon and Clarksburg. ${ }^{49}$ Unfort unately, it is impossible to determine precisely how many people deserted the western Virginia frontier due to the Indian war. Judging from first hand accounts, however, the number appears to have been large.

Not only did the Indian war prompt some settlers to leave trans-Allegheny Virginia, but it also appears to have had a negative impact on the number of new settlers arriving on the frontier. By examining the number of land grants issued to people who settled in Monongalia County for the years 1766 to 1782 , the discouraging effect of the Indian war becomes evident (table 1).

${ }^{48}$ Jacob Rees, deceased, v. William, Benjamin, and Mackinney Robinson, O.S. 44: N.S. 15, Augusta County Court House (bill filed in Harrison County on 21 August 1797).

${ }^{49}$ Alexander Scott Withers, Chronicles of Border Warfare (1895; reprint, Parsons, W. Va.: McClain 1989), 275. 
Table 1 .

Documented New Settlers in Monongalia County

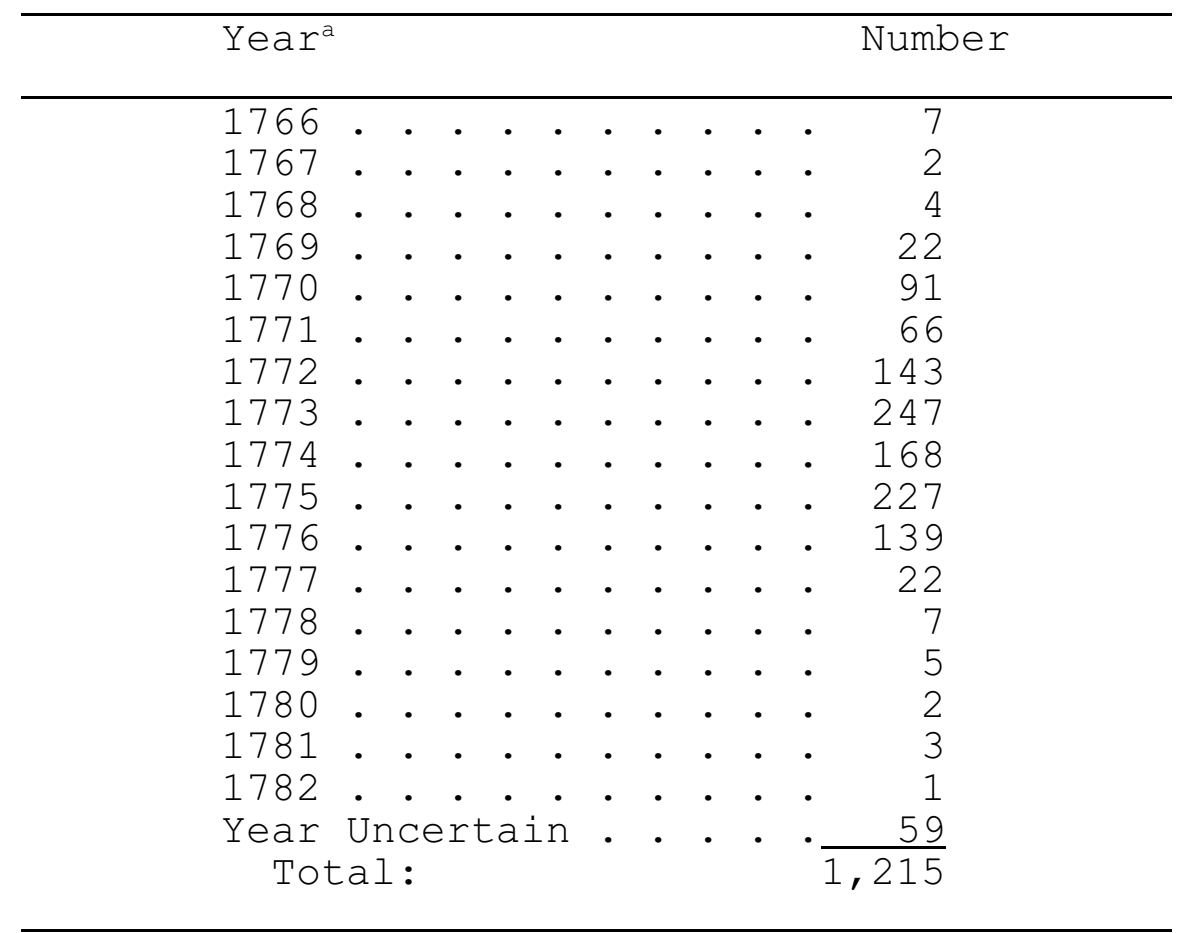

Source: Earl L. Core, Prelude, vol. 1 of The

Monongalia Story: A Bicentennial History

(Parsons, W. Va.: McClain, 1976), 158-59.

aThe year represents when the grantee settled

in Monongalia County, not when he formally

received his land grant.

The low number of settlements for the period 1766 to 1768 can be attributed to a combination of Pontiac's Uprising (1763-1765) and the Proclamation of 1763 forbidding settlement west of the Allegheny Mountains. In the fall of 1768, the first Fort Stanwix Treaty adjusted the proclamation line westward to coincide with the Ohio River thus legalizing the settlement of western Virginia. The following year, 1769, sees the beginning of a generally steady increase in the number of settlers arriving in Monongalia County. The relatively peaceful disposition of the Shawnees during the years 1769-1773 also contributed to the increase in set tlers. By 1774, however, the number of new arrivals had reached the crucial point where it hindered the Shawnees' pursuit of competency. The result was Lord Dunmore's War of 1774. The 32 percent drop that year in the number of new settlers reflected the dangerous conditions on the frontier. In 1775, the Shawnees, still stinging from their defeat at the Battle of Point Pleasant, remained at peace. Not surprisingly, the annual number of new settlers arriving in western 
Virginia almost returned to its pre-war level. By late 1776, however, the British had convinced many Shawnees to become allies in a war against the Americans. As war parties again began striking the backcountry settlements, there was a marked decline in the number of new families arriving in western Virginia. From 1776 through the end of the Revolution, the danger of Indian attacks discouraged settlement west of the mountains.

The depopulation that occurred in western Virginia during the first decade of the war had a negative effect on the econo mic development of the region. On a purely pragmatic level, it reduced the number of workers (producers) available for clearing the forest, droving cattle, distilling whiskey, and cultivating the soil. Depopulation, furthermore, stifled the development of the local economy by reducing the number of consumers in the potential market. Obviously, there is less incentive for businessmen and craftspersons to establish mercantile stores and shops where an already low population is experiencing further decline. Lastly, the drop in population reduced the revenue available to local governments. With fewer settlers paying taxes and fees, the counties had less money to hire employees and invest in local improvements such as roads and public buildings.

The population loss evoked by the Indian war was further accent uat ed when the Vir ginia Assembly began in 1775 to call up troops for service in the Continental Army. On nine different occasions between 1775 and 1782, the Assembly required each county to provide a portion of their militias. In 1782, for example, Ohio, Greenbrier, and Monongalia counties were ordered to send every fifteenth militiaman to the Continental Army. If insufficient volunteers failed to step forward, the difference was to be drafted into service. Considering that enlistments often lasted two years or more, western Virginia experienced a significant, albeit temporary, decline in population due to the Revolution. In 1776 alone, trans-Allegheny Virginia had to provide 735 able-bodied men to the Continental Army. The Assembly considered a man to be able-bodied if he was at least five feet four inches tall, possessed a healthy body and sound mind, and was between the ages of eighteen and fifty years. ${ }^{50}$ In other words, those settlers most capable of

${ }^{50}$ Virgil Lewis, The Soldiery of West Virginia (Charlest on, W. Va.: News-Mail Company, 1910), 39-43. 
clearing the land, planting crops, and building log cabins were also in high demand as soldiers in the east. By removing these workers from the backcountry settlements to serve in the army, the Revolutionary War in effect prolonged the "raw frontier" period of West Virginia history.

For those settlers who remained on the frontier, there was still the problem of how to contend with sporadic Indian attacks. Many settlers achieved physical security by moving their families and valuables into a nearby refuge fort whenever they believed danger was at hand. Although refuge forts mitigated the destruction caused by Indian attacks, retreating into forts for days or weeks at a time diverted the attention of settlers away from working their farms and improving their communities. It is, after all, difficult to clear new fields and protect ripening corn from squirrels when the entire family is living at a fort miles from the homestead. One settler observed that during times of danger, the entire countryside appeared deserted because everyone had moved to the forts. While away from their farms, unprotected livestock fell easy prey to wolves, bears, and mountain lions. Furthermore, free-range cattle and hogs got through fences into gardens and corn fields. Thus, after working hard to clear their land and plant crops, the settlers' need for security compelled them to periodically abandon their homesteads and move into crowded forts. $^{51}$ In effect, the settlers sacrificed their economic security (competency) in favor of physical security.

On occasion, armed work parties left the forts to perform chores at the various member's homesteads. While most of the work party members worked in the fields, one or two stood guard at strategic locations watching for any sign of Indians. Even through the use of such a system, how ever, most farms received only intermittent care throughout the summer. Not surprisingly, agricultural productivity tended to be lower than it would have been in peacetime. ${ }^{52}$

Throughout the twenty years of warfare in western Virginia, both the Shawnees and the sett lers effectively deprived one another of the full economic benefits of possessing the land and

${ }^{51}$ Doddridge, Notes, 109.

${ }^{52}$ Ibid. For a firsthand account of a work party being attacked by Indians near present Bridgep ort, West Virginia, see "The Declaration of William Robinson" in Tho mas Jefferson, Notes on the State of Virginia, ed. William Pedan (New York: Norton, 1954), 242. 
its resources. This resulted in a marked decline in the standard of living within both societies. By 1779, about half of the Shawnee nation had grown so weary of the death and suffering caused by the war that they decided to abandon their homeland rather than continue to fight. Under the leadership of chiefs Yellow Hawk and Black Stump, about half of the Shawnees left the upper Ohio Valley and moved down the Ohio River ultimately reaching present Missouri where they lived under the auspices of Spanish authorities. ${ }^{53}$ The remainder of the tribe continued to fight until General Anthony Wayne defeated them, along with most of the other tribes of the Old Northwest, at the Battle of Fallen Timbers near present Toledo, Ohio in 1794. The following year, the majority of the Shawnees' surviving chiefs ceded to the United States all of their tribal claims to the upper Ohio Valley. Removed from their land and resources, the once proud Shawnee nation languished as they tried to survive on meager annuity payments from the federal government. $^{54}$

Like the Shawnees, many settlers also experienced great hardship as a result of the war. Living on a remote frontier away from the conveniences of an established commercial market was difficult enough in peacetime, let alone during a protracted Indian war. If it had not been for the armed resistance of the Shawnee Indians, the ec ono mic development of the we stern Virginia frontier would have progressed much more rapidly than it did otherwise. The fact that the sett lement of trans-Allegheny Virginia coincided not only with an Indian war, but also with the Revolutionary War sets it a part from front iers that had been settled during peacetime. In some ways, the resistance of the Shawnees makes the western Virginia frontier more comparable to Massachu setts during King Philips War in 1676 than it is to the peaceful Shenandoah Valley in the late 1760s. ${ }^{55}$ While there can be no doubt that the people of Appalachian Virginia experienced a prolonged frontier, by no means did it extend into the early twentieth century as writer Horace

${ }^{53}$ Colin G. Calloway, The American Revolution in Indian Country: Crisis and Diversity in Native American Communities (New York: Cambridge University Press, 1995), 169-70.

${ }^{54}$ Janet Hubbard-Brown, The Shawnee (New York: Chelsea House, 1995), 76-77, 80-82.

${ }^{55}$ See Jill Lepore, The Name of War: King Philip's War and the Origins of American Identity (New York: Vintage Books, 1998. 
Kephart suggested. ${ }^{56}$ The next chapter shows that despite the remot eness, depopulation, and physical destruction experienced by the settlers during the late eighteenth century, they never abandoned the desire to employ commercial modes of production in their pursuit of competency.

${ }^{56}$ Horace Kephart, Our Southern Highlanders (New York: Outing Publishing Company, 1913), 18, 29-30, 33. 


\section{Chapter Four:}

Producing for the Market

Although household production was important to the settlers of trans-Allegheny Virginia, it had its limitations. For one thing, it could not provide them with every material comfort or convenience they desired. Muskets, black tea, Bibles, crosscut saws, indigo dye, and cast iron skillets all had to be carried across the mountains from the workshops or ports of Pennsylvania, Maryland, and eastern Virginia. To obtain these goods, the settlers needed cash, and to get cash they had to sell a commodity, whether it be farm produce, raw materials, or personal labor. Only by participating in the cash economy could the settlers achieve the level of competency they desired.

Even the widespread practice of trading work and borrowing tools from neighbors did not eliminate the need for participating in the commercial market. Not only had someone required cash to purchase the borrowed item in the first place, but the settlers also generally kept track of the approximate monetary value of these informal exchanges so as to make it easier to know how much one owed his neighbors. Even the barter system as manifested in western Virg inia depended on the commercial market to provide all of the necessary prices. ${ }^{1}$ For example, when customers at the Matthews Trading Post in the Greenbrier Valley bartered ginseng for consumer goods, the ginseng was first converted into its cash value, the "cash" was then credited to the customer's account, and then the customer used that credit to make purchases. ${ }^{2}$ Although no money changed hands, the entire transaction was based on both parties knowing the cash prices not only for the ginseng, but also for the store goods. In short, barter should not be viewed as an

${ }^{1}$ Paul Salstrom, "Subsistence-Barter-and-Borrow Systems: An Approach to West Virginia's Economic History," West Virginia History 51 (1992): 47, 51.

${ }^{2}$ Kenneth D. Swope, "Ginseng," Journal of the Greenbrier Historical Society 4 (1982): 107; Otis K. Rice, A History of Greenbrier County (Lewisburg, W.Va.: Greenbrier Historical Society, 1986), 102. 
alternative to the commercial economy. Instead, it is better interpreted as the settlers' pragmatic solution to the problem of living in a specie short market economy. ${ }^{3}$

Part icipation in a commercial economy is limited by several key factors. First, the prospective participant must possess a marketable commodity. For the settlers of western Virginia, these commodities included forest resources and agricultural products. Forest commodities, such as deer hides and ginseng, w ould have been available to the settlers in marketable quantities from the earliest days of settlement. Farm products, on the other hand, generally would not have been available in sufficient surpluses until after the destruction caused by Indian attacks had begun to decline after 1784 .

A second limiting factor is the small size of the market, or the number of individuals able to participate in the exchange of cash, credit, and commodities. ${ }^{4}$ The settlers who lived in western Virginia during the 1770 s and early 1780 s had two potential markets: the local market, and the eastern markets centered around the cities of Richmond, Baltimore, Alexandria, and Philadelphia. Generally speaking, the local market in most of western Virg inia offered few opportunities. The spars eness of the po pulation, particularly after the start of the Indian war, severely restricted the number of potential buyers and sellers. In addition, by discouraging settlement, the war effectively eliminated the opport unity for already established settlers to sell food, seed, and livestock to newcomers. ${ }^{5}$ Furthermore, few settlers would have po sses sed commodities that their neighbors did not already have access to, such as corn or deer hides. Finally, western Virginians did not enjoy the economic benefits associated with being situated along a major transportation

${ }^{3}$ Paul Salstrom, "Appalachia's Informal Economy and the Transition to Capitalism," Journal of Appalachian Studies 2 (1996): 225.

${ }^{4}$ L. Diane Barnes, "Avenues to a Market Economy: Harrison County, West Virginia, to 1860" (Master's thesis, West Virginia University, 1995), 1.

${ }^{5}$ See chapter three for a discussion of the impact that the Indian war had on the population of western Virginia. 
route as did farmers in the Shenandoah Valley who regularly sold food to travellers on the Great Wagon Road. ${ }^{6}$

A third factor which limited the settlers' ability to participate fully in the commercial econo my was the abs ence of adequa te transportation links with the eastern markets. As mentioned in a previous chapter, it was not until after the Revolutionary War that western Virginians upgraded their packhorse trails into fair weather wag on roads. Even afterward, the freight charges for bulky or heavy items were so high that it was simply not cost effective to transport grain, flour, and other similar agricultural products across the mountains. ${ }^{7}$

Despite the challenges posed by a small population, a distant market, po or transportation links, and destruction at the hands of marauding Indians, the settlers nevertheless found ways to participate in the commercial economy in order to secure their competencies. The backwoods commodities least affected by these limitations were deer hides and animal furs. The fur trade proved particularly attractive for a number of reasons. Furs were not perishable, they brought a high price in relation to their bulk, and they could be harvested, processed, and transported to a distant commercial center with minimal cash expenditures. In fact, a man could enter the commercial fur trade with just a gun, a few traps, and either a pack horse or canoe. In early 1791, for example, William Haymond, Jr. and Jonathan Cobun went on a hunting/trapping expedition along the waters of the Little Kanawha River. Travelling in a homemade canoe, they trapped several beavers and shot an otter, a buffalo, a four-hundred pound black bear, and several deer. Upon reaching the town of Marietta, in present Ohio, they sold the skins and meat for a cash profit. ${ }^{8}$

Although commercial hunting existed in western Virginia, it does not appear to have been as extensive as the South Carolina fur trade which produced 255,000 deer skins annually by the

${ }^{6}$ Robert D. Mitchell, Commercialism and Frontier: Perspectives on the Early Shenandoah Valley (Charlottesville: University Press of Virginia, 1977), 144.

${ }^{7}$ Leland D. Baldwin, Whiskey Rebels: The Story of a Frontier Uprising (Pittsburgh: University of Pittsburgh Press, 1939), 25.

${ }^{8}$ Haymond to Haymond, 6 April 1842 and 18 April 1842, William Haymond, Jr. Papers, West Virginia Regional and Hist ory Collection, West Virginia University. 
1730s. ${ }^{9}$ Unfortunately, a paucity of extant data precludes the calculation of precise figure s for the total number of skins exported from western Virginia during the late eighteenth century. Insight into the scale of the region's fur trade can be gained, however, by examining the account books of the Mathews Trading Post. Over a twenty month period from 9 August 1771 to 30 March 1773, proprietors Samson and George Mathews sent approximately 1,090 deer skins from their Greenbrier Valley store to their main store located in Staunton, Virginia. The majority of the skins came from customers who used them to pay on their accounts or to make purchases. Of the approximately four hundred customers named in the account books, only fifteen people exchanged deer skins on a regular basis. One man is listed as having sold approximately 230 skins at the store while two other customers exchanged over a hundred skins each. Most customers sold few or no skins at all. ${ }^{10}$ The entries in the account books suggest that while the fur trade was commercially import ant for some settlers, most people relegated it to a secondary position behind agriculture or the skilled trades.

Hunting "pest animals" was another way for settlers in western Virginia to earn cash. In an effort to rid the region of "dangerous" animals, the Virginia Assembly authorized county governments to pay bounties on the scalps of wolves. Under a 1764 law, the scalp of an adult wolf was valued at twelve shillings and six pence to the person submitting it to the county court. ${ }^{11}$ In 1782 , the Assembly amended the law by doubling the wolf bounty. ${ }^{12}$ To an extent, a scalp was as good as cash. In fact, the legal right to a wolf scalp could even be transferred from one person to another. ${ }^{13}$ Between 1787 and 1800, hunters in Randolph County collected bounties on 221

${ }^{9}$ Mitchell, Commercialism, 134; Wilma A. Dunaway, The First American Frontier: Transition to Capitalism in Southern Appalachia, 1700-1860 (Chapel Hill, University of North Carolina Press, 1996), 32.

${ }^{10}$ Harry E. Handley, "The Mathews Trading Post," Journal of the Greenbrier Historical Society 1 (1963): 8-14; Rice, History, 102.

${ }^{11}$ William Waller Hening, ed., The Statutes at Large; Being a Collection of All the Laws of Virginia, 1619-1792 (Richmond: 1809-23), 8:48.

${ }^{12}$ Ibid., 11:64.

${ }^{13}$ Nathaniel Cochran Papers, Prickett's Fort Memorial Foundation Archives, Fairmont, West Virginia. 
wolves. ${ }^{14}$ In the nineteenth century, the bounty laws of Virginia were broadened to include mountain lions, bears, bobcats, and foxes. ${ }^{15}$ Much like the fur trade, bounty hunting was an opportunity for settlers to earn cash.

Ginseng was ano ther forest commo dity that contributed to the competency of some pioneer families in western Virginia. Although the settlers themselves did not use the plant in their home remedies, it did have value on the world market. Traders in western Virginia and the Shenando ah Valley bought the herb from settlers who actively searched the forests for "sang patches." The traders then sent their dried ginseng to Philadelphia where it was loaded onto ships destined for the cities of Glasgow and London from which it was re-shipped to the Chinese who used it medicinally and as an aphrodisiac. ${ }^{16}$ Starting in 1784 , some American merchants began to ship ginseng directly to the Orient on their own vessels. ${ }^{17}$

Travellers in western Virginia frequently made reference to the settlers' practice of digging and selling ginseng. George Washington, for example, in September 1784 encountered "numbers of Persons and Pack horses . . . with Ginseng" heading east on Braddock's Road. ${ }^{18}$ Settlers in the Greenbrier Valley also regularly sold and traded the herb at the Mathews Trading Post. On 3 December 1772, for example, James Donaley traded forty-five pounds of ginseng for "knee buckles, fur hat, flannel, a comb and six yards of ozgns [osnaburg]." Nineteen days later, Robert Sconce arrived at the post laden with one hundred twenty-six pounds of ginseng for which he was

${ }^{14} \mathrm{Hu}$ Maxwell, The History of Randolph County, West Virginia (1898; reprint, Parsons, W. Va.: McClain, 1991), 216.

${ }^{15}$ William P. McNeel, "Pocaho ntas County," in History of Pocahontas County, West Virginia (Marlinton, W.Va.: Pocaho ntas county Historical Society, 1981), 21 ; Maxwell, Randolph, 216.

${ }^{16}$ Durwood Dunn, Cades Cove: The Life and Death of a Southern Appalachian Community, 1818-1937 (Knoxville: University of Tennessee Press, 1988), 30-32; Mitchell, Commercialism, 182.

${ }^{17}$ Kim Derek Pritts, Ginseng: How to Find, Grow, and Use America's Forest Gold (Mechanicsburg, Pa.: Stackpole Books, 1995), 23.

${ }^{18}$ Earl L. Core, The Pioneers, vol. 2 of The Monongalia Story: A Bicentennial History (Parsons, W. Va.: McClain, 1976), 113. 
paid nine pounds, nine shillings. In all, the ac count books name nine settlers who paid their accounts at the store with forty or more pounds of ginseng. ${ }^{19}$

In some instances, settlers gathered natural resourc es and cultivated produce on a scale that generated marketable surpluses in excess of that needed to achieve competency. Daniel Boone's involvement with the fur and ginseng trade exemplifies this sort of small scale backcountry capitalism. After the Revolutionary War, Boone began supplying eastern merchants with ginseng from the Ohio Valley. In 1787, he along with several hired hands began digging all the ginseng they could find in western Virginia and eastern Kentucky. In addition, he purchased ginseng from fellow settlers. The following spring, he loaded fifteen tons of ginseng into a boat and started up the Ohio River toward Pittsburgh. Unfortunately, his boat sank near Point Pleasant and he lost a portion of his precious cargo. Although the accident cost Boone dearly, he was not about to be deterred. By 1790, he was back at Point Pleasant where he opened a trading post that specialized in ginseng and furs. The scale of Boone's business is evidenced by a letter he received from a Maryland merchant who confirmed that Boone's shipment of two barrels of ginseng, 1,790 deer skins, 129 bear skins, and otter skins had arrived safely. Within two years, however, Boone's trading business had gone the same way as his land speculation deals, and he found himself deep in debt. ${ }^{20}$

By no means did the settlers of western Virginia limit themselves to the marketing of forest resources. After all, most settlers were farmers who practiced a diversified type of agriculture that included not only grain and vegetable production, but also the herding of cattle, hogs, and sheep. ${ }^{21}$ Much like their kinsmen in eastern Pennsylvania and the Shenandoah Valley, western farmers sought to produce crops that had value not only within their own homes, but also on the commercial market. Potential markets for western Virginia farmers included the sugar

${ }^{19}$ Kenneth D. Swope, "Ginseng," 107; Rice, History, 102-3.

${ }^{20}$ Pritts, Ginseng, 24; John Mack Faragher, Daniel Boone: The Life and Legend of an American Pioneer (New York: Henry Holt and Company, 1992), 264-65.

${ }^{21}$ Mitchell, Commercialism, 133; Barbara Rasmussen, Absentee Landowning and Exploitation in West Virginia, 1760-1920 (Lexington: University Press of Kentucky, 1994), 32. 
islands of the West Indies where the best land was used for raising sugar cane rather than food; the growing urban centers of the eastern United States; and western Europe where a rising population had begun to outpace domestic food production. ${ }^{22}$ In the 1790 s, yet another market opened in the lower Ohio Valley with the arrival of settlers in western Kentucky, southern Indiana, and southern Illinois. In fact, by 1795, farmers from western Virginia had begun to raise wheat, potatoes, apples, and pork for the New Orleans market. ${ }^{23}$

A major obstacle faced by mountain farmers was the lack of an adequate transportation network linking western Virginia with these external markets. Although wagon roads had been constructed across the Allegheny Mountains by the 1790s, their poor quality rendered them of little value for carrying large scale commerce. ${ }^{24}$ Even the Ohio and Monongahela rivers presented obstacles to commerce in the form of submerged rocks, tree trunks, "sweepers," and widely fluctuating water levels. Harrison county resident John G. Jackson recognized the importance of river channel impro vement for transportation and commerce within western Virginia. Partially through his efforts, the Virginia Assembly in 1793 authorized the clearing of logs, rocks, and other obstacles from the channel of the upper Monongahela River and its tributaries. In 1800, the legislature took further action by designating the Monongahela River a public highway, and required all mill owners to build slopes for their dams. ${ }^{25}$ Although these water improvements fostered commerce within the region, what farmers really needed was a quality wagon road across the Allegheny Mountains.

Poor transportation links particularly affected grain farmers in western Virginia. The shear bulk of corn, rye, and wheat crops prevented it from being hauled over the mountains in a cost

${ }^{22}$ Richard K. MacMaster, "The Cattle Trade in Western Virg inia, 1760-1830," in Appalachian Frontiers: Settlement, Society, and Development in the Preindustrial Era, ed. Robert D. Mitchell (Lexington: University Press of Kentucky, 1990), 133; Rasmussen, Absentee, 32.

${ }^{23}$ Rasmussen, Absentee, 32, 34.

${ }^{24}$ Core, Pioneers, 249.

${ }^{25}$ Stephen W. Brown, Voice of the New West: John G. Jackson and His Times (Macon, Ga.: Mercer University Press, 1985), 34. 
effective manner. ${ }^{26}$ Freight wagons were of little use due to the ruggedness of mountain roads, and it would have required an inordinate number of pack horses to use caravans. To transport the harvest from even four acres of corn, for example, would have required about twenty-four animals. ${ }^{27}$ One solution to this problem involved reducing the volume of the crop by distilling it into whiskey. In doing this, a twenty-four bushel harvest of rye could be converted into just sixteen gallons of whiskey; a load that even a single pack horse could handle. ${ }^{28}$ Dist illing rye became so widespread in northwestern Virginia that by 1790, approximately one out of every eight settlers owned a still. Those people who could not afford to buy one themselves sometimes pooled their money with friends and relatives and bought one together. By the mid-1790s, Monongahela rye whiskey had established a niche among consumers not only in the east, but also in New Orleans which received periodic flatboat shipments via the Ohio and Mississippi rivers. ${ }^{29}$

Another option for disposing of grain involved feeding it to ho gs and cattle which could later be driven to eastern markets on hoof. ${ }^{30}$ Settlers involved in this activity generally fell into two categories: 1) those who sold surplus livestock on an opportunistic basis, and 2) those who specialized in livestock grazing for the specific purpose of supplying eastern markets. To determine how many settlers may have been engaged in each of these categories, it is necessary to know the number of people in each pioneer household, the number of cattle necessary for subsistence purposes, and the size of each person's cattle herd. By subtracting the number of cattle needed for subsistence from the total number owned, it is possible to calculate the number of settlers who could have sold surplus animals without jeopardizing their competency.

${ }^{26}$ Ibid., 191.

${ }^{27}$ Calculation based on information from James T. Lemon, The Best Poor Man's Country: A Geographical Study of Early Southeastern Pennsylvania (Baltimore: Johns hopkins Press, 1972), 152; and Core, Pioneers, 177-78.

${ }^{28}$ Baldwin, Whiskey, 25; Lemon, Best, 152.

${ }^{29}$ Core, Pioneers, 177-79 .

${ }^{30}$ Eugene J. Wilhelm, "Animal Drives: A Case Study in Historical Geography," The Journal of Geography 66 (1967): 332. 
Unfortunately, there is insufficient documentation to permit this sort of direct comparison betwe en specific household sizes and cattle holdings. Still, it would be beneficial to examine the extant data and make some general observations.

Using Monongalia County in 1782 as a representative sample of households in western Virginia, it is possible to calculate the mean household size for the frontier population (table 2).

Table 2 .

Household Size in Monongalia County, 1782

\begin{tabular}{lcc}
\hline Number in & Number of & Percentage of \\
Household & Households & Households
\end{tabular}

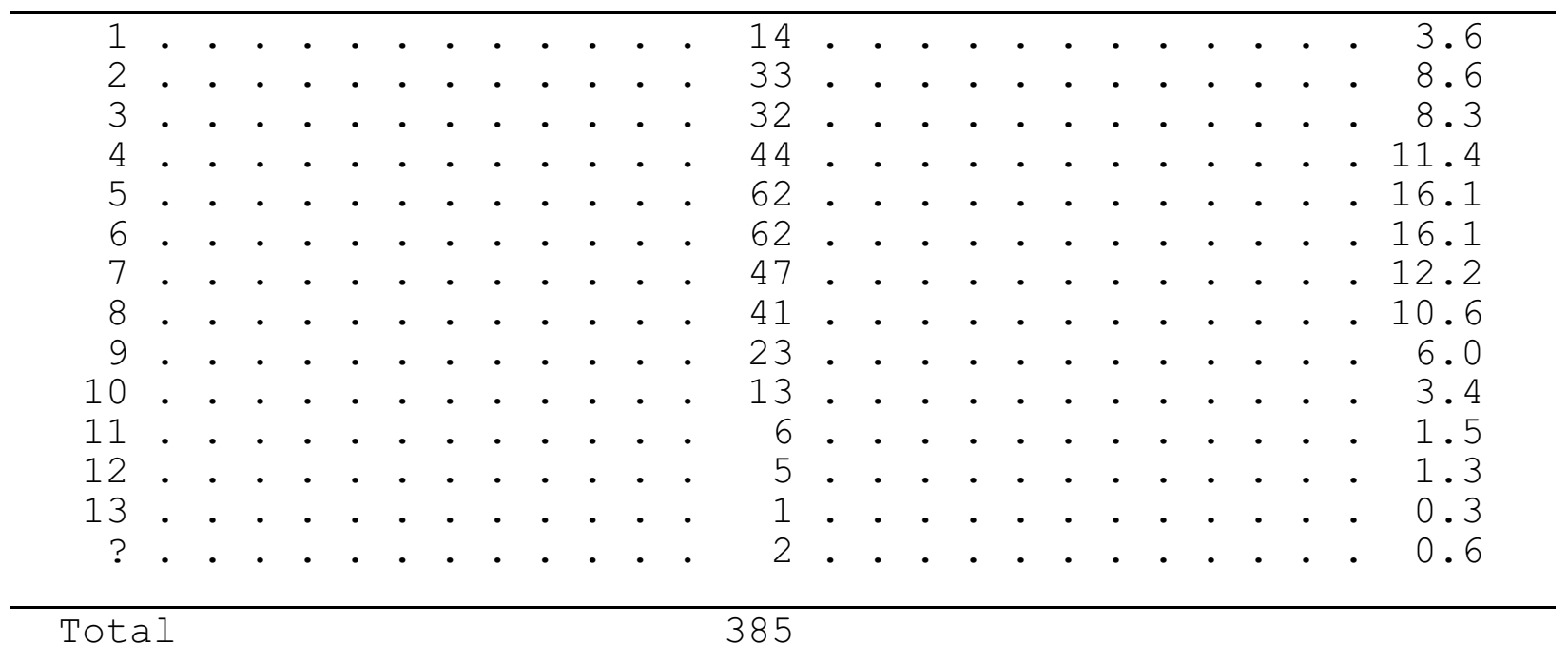

Total

Source: Based on raw data in Core, Pioneers, 525-30. aThis number includes only white people.

Based on the above data, Monongalia County in 1782 contained 2,169 white people in 385 different hou seholds. The mean household in western Virginia contained 5.6 individuals. This number is particularly significant considering that historical geographer James T. Lemon determined that a family of five required the products from five cows and half a steer to provide for their annual subsistence needs. ${ }^{31}$ If 5 people required 5.5 cattle, it can be extrapolated that 5.6 people required the products of about 6.1 cattle to sustain a competency.

Considering that a "typical" frontier family needed to keep a herd of about six animals, it would be valuable to know how many people actually maintained herds of this size. An analysis

${ }^{31}$ Mitchell, Commercialism, 141. 
of cattle ownership based on the 1787 county property tax assessments for Harrison, Monongalia, and Randolph counties provides insight into this question (table 3).

Table 3 .

Cattle Herds in Select Western Virginia Counties, 1787

\begin{tabular}{|c|c|c|c|c|c|}
\hline \multirow[b]{2}{*}{ county } & \multirow{2}{*}{$\begin{array}{l}\text { Number of } \\
\text { People Assessed } \\
\text { with Cattle }\end{array}$} & \multicolumn{4}{|c|}{ Number of Cattle } \\
\hline & & $1-6$ & $7-12$ & $13-19$ & $20+$ \\
\hline Harrison & 231 & 148 & 56 & 24 & 3 \\
\hline Monongalia ${ }^{a}$ & 266 & 189 & 61 & 15 & 1 \\
\hline Randolph & 144 & 65 & 55 & 17 & 7 \\
\hline Totals: & 641 & 402 & 172 & 56 & 11 \\
\hline
\end{tabular}

Source: County personal property tax lists for 1787. aMonongalia County was divided into three tax districts. Only two of the district tax lists are extant.

Property owners with six or few er cattle comprised 64 percent of tho se asses sed with herds in Harrison County, 71 percent in Monongalia County, and 45 percent in Randolph County.

Considered together, a majority of about 60 percent of those settlers with cattle in the above three counties would not have had surplus stock to sell commercially if they also had to support a "typical" household of 5.6 people. Regardless of the precise household size for these small time herders, it is doubtful that any of them could have sold more than one steer per year on an opportunistic basis.

Nor can it be as sumed that people asses sed at between seven and nineteen head of cattle would have been in any better position to market more than one or two surplus steers per year. Thirty-six percent of frontier households were comprised of seven to thirteen people. For them to achieve their subsistence in cattle, approximately 36 percent of the herds in the region likewise must have ranged in size from seven to fourteen animals since about one animal per person was necessary for subsistence purposes. As it turns out, the crucial 36 percent can be achieved only by considering herds that ranged in size from seven to nineteen animals. In other words, even settlers with medium-sized herds of cattle probably could not have afforded to spare more than one or two steers per year. 
Within each of the three counties, a smallminority of settlers possessed herds in excess of twenty cattle. Although it would be tempting to declare that these settlers might have been involved in commercial cattle grazing, such a conclusion would be premature. One factor which has not yet been taken into consideration are the African Americans who lived in the three selected counties. Overall, African Americans comprised a small percentage of the population in the counties of Harrison, Monongalia, and Randolph. Extant documents reveal that eighty-one African Americans lived in Monongalia County in $1782 .{ }^{32}$ In other words, they comprised approximately 3.6 percent of the total population. With very few exceptions, most of them were slaves. It is crucial to our current discussion to know the distribution of slaves within the individual settlers' households because of the impact that large slave holdings would have had on the number of cattle necessary for a household to achieve a competency. Eighteenth century Virginians considered slaves to be taxable property, therefore, they appear alongside cattle on county tax assessments. This permits not only an analysis of slave distribution, but also a comparison between slave holding and herd size (tables 4 and 5).

Table 4. Slave Ownership in Select Western Virginia Counties, 1787

\begin{tabular}{|c|c|c|c|c|c|c|c|c|c|c|c|c|c|}
\hline \multirow[b]{2}{*}{ County } & \multirow{2}{*}{$\begin{array}{l}\text { Total } \\
\text { People } \\
\text { Assessed }\end{array}$} & \multicolumn{12}{|c|}{ Number of Slaves } \\
\hline & & 0 & 1 & 2 & 3 & 4 & 5 & 6 & 7 & 8 & 9 & 10 & 14 \\
\hline$\overline{\mathrm{Har}}$ & 277 & 261 & 10 & 3 & 0 & 1 & 0 & & 0 & 0 & 0 & 0 & 1 \\
\hline Monongalia & 318 & 289 & 11 & 3 & 4 & 6 & 1 & 1 & 2 & 1 & 0 & 0 & 0 \\
\hline Randolph & 185 & 178 & 2 & 0 & 2 & 0 & 0 & 2 & 1 & 0 & 0 & 0 & 0 \\
\hline
\end{tabular}

Source: County personal property tax lists for 1787. Monongalia County was divided into three tax districts. Only two of the district tax lists are extant.

Whereas demonstrated by table 4 , only a minority of the as sessed population within each of the three counties owned any slaves at all. Slave ownership was confined to 5.7 percent of those assessed in Harrison County, 9.1 percent in Monongalia County, and 3.8 percent in Randolph County. The implication of having so few slave holders is that between 90 and 96 percent of the

\footnotetext{
${ }^{32}$ Core, Pioneers, 177.
} 
assessed population for each of the three counties would not have had to maintain extra cattle to help feed slaves. The lack of responsibility for maintaining slaves enabled settlers to sell more of their stock than would have been possible had they owned slaves.

But what about those few settlers that owned tw enty or more head of cattle? As can be seen in table 5, there appears to have be en a slight correlation between status as a slave holder and number of cattle owned.

Table 5 .

Settlers Assessed for Twenty or More Cattle, 1787

\begin{tabular}{llcc}
\hline Name & County & Slaves & Cattle \\
\hline John Warwick & Randolph & 7 & 69 \\
Aron Richardson & Randolph & 0 & 41 \\
Thomas Wilmouth & Randolph & 0 & 30 \\
Benjamin Wilson & Harrison & 2 & 30 \\
William Dougherty & Monongalia & 0 & 27 \\
Edward Jackson & Randolph & 0 & 26 \\
John Crouch, Jr. & Randolph & 0 & 23 \\
John Powers & Harrison & 2 & 22 \\
William Robinson & Harrison & 0 & 22 \\
Jacob Stalnaker, Jr. & Randolph & 0 & 21 \\
Charles Fornelson, Sr. & Randolph & 0 &
\end{tabular}

Source: County personal property tax lists for 1787.

Where approximately 7 perc ent of the general front ier population held slaves, 27 percent of the largest cattle owners owned them. Although owning slaves would have required a settler to maintain extra cattle to provide for the slaves' subsistence, the wealthiest herders generally owned many more cattle than subsistence would have required. Also significant is the fact that eight of the largest cattle holders owned no slaves at all. Knowing this, it can be concluded that those settlers with more than twenty cattle did not maintain such sizable herds to feed their households or large gangs of slaves. More likely than not, they were producing large cattle surplus es for the commercial market.

Regardless of whether livestock was raised on a large or small scale, a settler derived no income from his efforts until his cattle had been successfully marketed. Sometimes, the market came to the settler in the form of professional drovers who had been hired by merchants to travel throughout the settlements soliciting marketable steers from each homestead. As the drover 
progressed through the backcountry, he gradually accumulated a herd that he would drive over the mountains to the Shenandoah Valley. The city of Winchester in the lower Valley served as an important center for the western Virginia cattle trade..$^{33}$ In 1793, the Reverend Harry Toulmin noted in his journal the "multiplicity of cattle which pour through this town from the backcountry. ${ }^{134}$ In Winchester, drovers had the option of selling the cattle immediately or driving the herd onward to the markets of Baltimore, Philadelphia, Alexandria, or even New York. ${ }^{35}$

Individual set tlers sometimes took the initiative by driving their own cattle to the Shenando ah Valley markets. Generally, "mount ain drives" involved only a handful of animals and two or three drovers. With so few workers, each cow nomally wore a bell around its neck to help the drovers locate it in the event that it strayed. Few settlers ever had to go beyond the Shenandoah Valley in search of a buyer due to the large number of merchants and professional drovers that frequented the Winchester marketplace. After selling their cattle, the settlers typically purchased any needed supplies before returning home across the mountains. ${ }^{36}$ After being sold, the cattle were placed in temporary holding areas until enough had been assembled to merit a large scale drive to the east. Upon their arrival in cities such as Philadelphia, merchants had the cattle butchered, salted, barreled, and shipped either to the West Indies or to western Europe. In this way, the settlers of western Virginia helped to feed people throughout the Atlantic community while at the same time providing for their own competencies. ${ }^{37}$

${ }^{33}$ MacMaster, "Cattle," 132-33, 135, 147.

${ }^{34}$ Harry Toulmin, The Western Country in 1793: Reports on Kentucky and Virginia, eds., M. Tinling and G. C. David (San Marino, Calif: Castle Press, 1948), 111-12.

${ }^{35}$ Paul R. Lilly, "The Drovers," Journal of the Greenbrier Historical Society 4 (1986): 13; Salstrom, Appalachia's, 6; Mitchell, Commercialism, 149.

${ }^{36}$ Wilhelm, "Animal," 332-33; Mitchell, Commercialism, 186; Doddridge, Notes, 97-98.

${ }^{37}$ MacMaster, "Cattle," 133; Richard B. Sheridan, Sugar and Slavery: An Economic History of the British West Indies, 1623-1775 (Baltimore: Johns Hopkins University Press, 1973), 105-7, 315. 
By no means did the settlers limit themselves to the commercial production of cattle. They also raised surplus hogs for the marketplace. ${ }^{38}$ Unfortunately, the Vir ginia legislature did not require swine to be enumerated in personal property as sess ments, therefore, much less is known about them. Extant wills and estate inventories provide some insight into the numbers of hogs maintained by the settlers, however the sample is so small that the enumerated results can not be generalized with any degree of validity. In Monongalia County, for example, only nine inventories taken prior to the nineteenth century have survived, and according to them, settlers owned anywhere from zero to thirty-six hogs. ${ }^{39}$

In a few cases, anecdotal references to the marketing of hogs can be found in the county court and militia records. For example, in 1750, Jacob Coger was brought before the Augusta County court for a "breach of the peace, by driving hogs over the Blue Ridge on the Sabbath day." ${ }^{40}$ In addition, some settlers are documented as having sold pork and bacon to companies of county militia stationed at nearby refuge forts. ${ }^{41}$ Although such evidence verifies that some settlers sold pork commercially, there is no way of determining the ext ent of the practice. The relative paucity of documentation on the marketing of hogs during the late eighteenth century compared with the abundance of documentation for the early nineteenth century suggests that commercial hog production was of overall minor importance to most of the earliest settlers in western Virginia. ${ }^{42}$

Although most settlers worked primarily as farmers, many of them supplemented their agricultural endeavors by producing manufactured goods or professional services. Once again,

${ }^{38}$ Mitchell, Commercialism, 186.

${ }^{39}$ Monongalia County Estates Book 1, 7, 45-46.

${ }^{40}$ John R. Commons et al, eds., Plantation and Frontier, vol. 2 of A Documentary History of American Industrial Society (New York: Russell and Russell, 1958), 287. n.d), 11 .

${ }^{41}$ Henry Haymond, Historical References to Pricketts' Fort and Its Defenders. . . . (N.p.,

${ }^{42}$ On hog drives across southwestern Virginia during the early nineteenth century, see Mary Verhoeff, The Kentucky Mountains: Transportation and Commerce, 1750 to 1911, Filson Club Publication 26 (Louisville: John P. Morton, 1911), 99; and Charles Henry Ambler and Festus P. Summers, West Virginia: The Mountain State (New York: Prentice-Hall, 1940), 219. 
the account books from the Mathews Trading Post provide insight into this aspect of the backcountry economy. In an effort to clearly identify who an account belonged to, the account ant sometimes noted the occupation of a particular customer beside his name. Listed in the books were three blacksmiths, one shoemaker, one sadler, two sto ne masons, one cooper, two weavers, one gunsmith, two carpenters, three tailors, one sawyer, two merchants, one miller, two packhorsemen, and seven jobbers. In all, at least twenty-nine of the approximately four hundred named customers did significant amounts of work in professions other than, or in addition to, agriculture. $^{43}$

Even the Mathews trading post itself exemplifies the economically diversified nature of the backcountry economy. At its most basic level, the post served as a store where settlers purchased both necessities and luxuries. Much of the inventory was tailored toward providing tools and supplies to mountain farmers. The Mathews brothers stocked nails, weeding hoes, grubbing hoes, chisels, axes, awls, hand saws, saddles, girths, gimlets, files, hasps, almanacs, cuttoe knives, bits and bridles, rasps, and drawing knives. The brothers also sold everything a frontiersman might require to shoot his flintlock rifle including powder, lead, flint, and replacement ramrods. For use in the home, the store carried dishes, needles, pen knives, trunks, padlocks, knives and forks, bed ticks, bags, alum, indigo, pins, cups, blankets, combs, mirrors, knitting needles, paper, pots, buckles, and thimbles. Luxury items available at the store included books, silk handkerchiefs, playing cards, flowered cloth, ribbons, and ready made clothing such as leggings, garters, and shoes. The shear variety of consumer goods purchased by the Mathews' customers suggests that when possible, the settlers readily engaged in the commercial economy as a means of achieving a comfortable lifestyle somewhat above the level of mere subsistence. ${ }^{44}$

In addition to operating as a store, the post in many ways also functioned as a bank. It lent money to customers, charged interest on accounts, transferred money from one account to another, and even paid customer's land taxes to the sheriff. In addition to lending money, the

${ }^{43}$ Rice, History, 103.

${ }^{44}$ Handley, "Mathews," 8- 14; Frances Alderson Swope, comp., "The Mathews Trading Post Ledger, 1771-1779," Journal of the Greenbrier Historical Society 4 (1984), 20-60. 
account books also indicate that the post rented out tools. In 1773, for example, Edward Wilson's account was charged for the use of a whipsaw. The sto re even lent some farmers grain and corn seed for spring plantings. Three customers went to the store to have watches repaired, and three customers paid for weaving. In fact, a number of customers even paid the post for having their horses shod. Patrons also bought meals at the post, ordered bespoke clothing, and sold their rights to wolf scalps. On one occasion, a customer purchased a male servant of an unspecified race. In practice, the Mathews trading post gave real meaning to the term "general store" by providing the early Greenbrier settlers with a multitude of commercial services. ${ }^{45}$

The commercial economic structures revealed in the Mathews brothers' account ledgers are by no means particular to the Greenbrier Valley. Similar, albeit less well documented, commercial patterns operat ed throughout the western Virginia frontier. Backcountry trading posts served as important links in the economic chain that connected the individual pioneer households to the greater Atlantic economy. By engaging in the commercial market as both producers and consumers of a wide range of commodities and services, the pioneers achieved levels of competency that would have been impossible to attain solely through the use of subsistence means of production. It is somewhat ironic that many classic symbols of pioneer selfsufficiency, such as flint lock rifles, double-bit axes, Bibles, and cast iron cookware, could generally be acquired only through the use of commercial economic structures.

${ }^{45}$ Ibid. 
Chapter Five:

Conclusion

For over two cent uries, political theorists, government policy makers, novelists, movie producers, and the general public have looked toward the pioneers of Appalachia with preconceived notions of what they would find. Frequently, the "reality" they detected was geared toward furthering a particular political, philosophical, or social end. In the late eighteenth century, for example, Thomas Jefferson saw in rural farmers an alternative to the alleged degenerate manners and principles of urban European factory workers. Jefferson argued that "those who labor in the earth are the chosen people of God" because of their ec onomic independence, innate virtue, "happiness, and permanence of government." ${ }^{11}$ Jefferson's image of the self-sufficient backcountry farmer served him well in his efforts to construct a philosophical basis for American independence from England.

A century later, the influx of millions of Catholic immigrants from southern and eastern Europe prompted nativistic Americans to seek reassurance that the "Anglo-Saxon" way of life would persist in the United States. Concerned nativists looked upon the Appalachian descendants of the pioneers as having inherited and retained the Anglo-Saxon virtues of democracy, freedom, and self-sufficiency. By somehow tapping into this reserve, they believed that the cultural purity of Anglo-Saxon America might be preserved. ${ }^{2}$ Like Jefferson, nativists saw largely what they looked for in the inhabitants of the southern Appalachian Mountains. They saw a people whose daily lives embo died the republican virtues of independence and self-sufficiency. Although this image is appealing to many modern ind ividual-minded Americans, it is wrong, particularly in regard to economic independence.

${ }^{1}$ Thomas Jefferson, Notes on the State of Virginia, ed. William Pedan (New York: W. W. Norton, 1954), 164-65.

${ }^{2}$ Allen W. Batteau, The Invention of Appalachia (Tucson: University of Arizona Press, 1990), 60-61, 63. 
Hopefully, this study has helped to undermine the fac ade of pioneer economic independence by showing that the domestic economy of the settlers in western Virginia was much more complex than the popularized "pioneer image" suggests. Rather than rely solely on pure subsistence modes of production to provide for their daily needs, the settlers employed a combination of both subsistence and commercial economic endeavors.

In the greater scheme, this conclusion serves as yet one more nail in the coffin of Appalachian exceptionalism. Those men and women who set tled in western Virginia during the eighteenth century were no less commercial-minded than the people of eastern Pennsylvania or the Shenandoah Valley. Neither did they embody a special reserve of "agrarian virtue" or "pure Anglo-Saxonism." If there is a fundamental difference between the people who lived on opposite sides of the Allegheny Mountains, it resides only in the perceptions of writers, government policy makers, movie moguls, and the general public. In short, the self-sufficient pioneer image is more a perception than a reality. 
Bibliography

Primary Sources

$\underline{\text { Manuscripts }}$

Fairmont, West Virginia

Pricketts Fort Memorial Foundation Archives

Cochrane, Nathaniel. Papers.

Prickett, J. Miles. Papers

Wilcox, William J. "History of Pricketts Fort." Unpublished manuscript.

Morgantown, West Virginia

West Virginia and Regional History Collection, West Virginia University

Draper Manuscripts. Microfilm.

Haymond Family. Papers.

Haymond, Luther. Papers.

Richmond, Virginia

Virginia State Archives

Fort Pitt Pay Book.

Winchester, Virginia

Handley Library Archives

Cunningham, Jerry. Papers.

$\underline{\text { Newspapers }}$

The Fairmont Times 1919

The Fairmont West-Virginian 1919

$\underline{\text { Books }}$

Aristotle. "Aristotle on Politics." In Sources in Greek Political Thought, from Homer to Polybius, edited by Donald Kagan. New York: Free Press, 1965.

Asbury, Francis. The Journals and Letters of Francis Asbury. 3 vols. Nashville: Abingdon Press, 1958.

Bockstrock, Lloyd DeWitt. Virginia's Colonial Soldiers. Baltimore: Genealogical Publishing Company, 1988. 
Browning, Meshach. Forty-Four Years of the Life of a Hunter. Winston-Salem, N. C.: Winston Printing Company, 1942.

Butterfield, C. W. The Washington-Crawford Letters Being the Correspondence between George Washington and William Crawford from 1767-1781. Cincinnati: Robert Clarke, 1877.

Commons, John R., Ulrich B. Phillips, Eugene A. Gilmore, Helen L. Sumner, and John B. Andrews., eds. A Documentary History of American Industrial Society. Vol. 2, Plantation and Frontier. New York: Russell and Russell, 1958.

Doddridge, Joseph. Notes on the Settlement and Indian Wars. 1912. Reprint. Parsons, W.Va.: McClain, 1989.

Hening, William Waller., ed. The Statutes at Large; Being a Collection of All the Laws of Virginia, 1619-1792. 13 vols. Richmond: 1809-23.

Hulbert, Archer Butler, ed. Washington and the West: Being George Washington's Diary of September, 1784. Kept during His Journey into the Ohio Basin in the Interest of a Commercial Union between the Great Lakes and the Potomac River. New York: Century, 1905.

Jefferson, Thomas. Notes on the State of Virginia. Edited by William Pedan. New York: W. W. Norton, 1954.

Kappler, Charles J., ed. Indian Treaties, 1778-1883. New York: Interland Publishing, 1972.

Kellogg, Louise Phelps, ed. Frontier Advance on the Upper Ohio, 1778-1779. Madison: Wisconsin Historical Society, 1916.

[Lederer, John]. The Discoveries of John Lederer. Edited by William P. Cumming. Charlottesville: University Press of Virginia, 1958.

Lewis, Ronald L., and John C. Hennen Jr., eds. West Virginia: Documents in the History of a Rural-Industrial State. Dubuque, Iowa: Kendall/Hunt, 1991.

Lewis, Thomas. The Farfax Line: Thomas Lewis's Journal of 1746. New Market, Va.: Henkel Press, 1925.

Schoepf, Johann David. Travels in the Confederation, 1783-1784. Vol. 1. Edited by Alfred J. Morrison. New York: Burt Franklin, 1986.

Schreiner-Yantis, Netti. The Personal Property Tax Lists for the Year 1787 for Greenbrier County, Virginia. Springfield, Va.: Genealogical Books in Print, 1987.

. The Personal Property Tax Lists for the Year 1787 for Harrison County, Virginia. Springfield, Va.: Genealogical Books in Print, 1987.

. The Personal Property Tax Lists for the Years 1786, 1787 (partial) and 1788 for Monongalia County, Virginia. Springfield, Va.: Genealogical Books in Print, 1987.

. The Personal Property Tax Lists for the Year 1787 for Randolph County, Virginia. Springfield, Va.: Genealogical Books in Print, 1987.

Smyth, J. F. D. A Tour of the United States of America, Vol. 1. 1774. Reprint. New York: Arno Press, 1968. 
Stuart, John. Memoir of Indian Wars, and Other Occurrences. 1833. Reprint. Parsons, W.Va.: McClain, 1971.

Thwaites, Reuben G., ed. Early Western Travels. 32 vols. Cleveland: Arthur H. Clark Co., 19047.

Thwaites, Reuben G. and Louise P. Kellogg, eds. Documentary History of Dunmore's War, 1774. Madison: Wisconsin Historical Society, 1905. 1912.

Toulmin, Harry. The Western Country in 1793: Reports on Kentucky and Virginia. Edited by M. Tinling and G. C. David. San Marino, Calif: Castle Press, 1948.

\section{Secondary Sources}

$\underline{\text { Books }}$

Abernathy, Thomas Perkins. Western Lands and the American Revolution. New York: Russell and Russell, 1959.

. Three Virginia Frontiers. 1940. Reprint. Gloucester, Mass.: Peter Smith, 1962.

Alford, Thomas Wildcat. Civilization: As Told to Florence Drake. Norman: University of Oklahoma Press, 1936.

Alvord, Clarence Walworth, and Lee Bidgood. The First Explorations of the Trans-Allegheny Region by the Virginians, 1650-1674. Cleveland: Arthur H. Clark Company, 1912.

Ambler, Charles Henry. A History of Transportation in the Ohio Valley. Glendale, Calif: Arthur H. Clark, 1931.

Ambler, Charles Henry and Festus P. Summers. West Virginia: The Mountain State. New York: Prentice-Hall, 1940.

Appleby, Joyce. Capitalism and a New Social Order: The Republican Vision of the 1790s. New York: New York University Press, 1984.

Axtell, James. ed., The Indian Peoples of Eastern America: A Documentary History of the Sexes. New York: Oxford University Press, 1981).

. The Invasion Within: The Contest of Cultures in Colonial North America. New York: Oxford University Press, 1985.

Bailyn, Bernard and Philip D. Morgan., eds. Strangers Within the Realm: Cultural Margins of the First British Empire. Chapel Hill: University of North Carolina Press, 1991.

Baldwin, Leland D. Whiskey Rebels: The Story of a Frontier Uprising. Pittsburgh: University of Pittsburgh Press, 1939.

Batteau, Allen W. The Invention of Appalachia. Tucson: University of Arizona Press, 1990. 
Baugh, Timothy G. and Jonathan E. Ericson, eds. Prehistoric Exchange Systems in North America. New York: Plenum Press, 1994.

Briceland, Alan Vance. Westward from Virginia: The Exploration of the Virginia-Carolina Frontier, 1650-1710. Charlottesville: University Press of Virginia, 1987.

Brown, Stephen W. Voice of the New West: John Jackson His Life and Times. Macon, Ga: Mercer University Press, 1985.

Buck, Solon J. and Elizabeth Hawthorn Buck. The Planting of Civilization in Western Pennsylvania. Pittsburgh: University of Pittsburgh Press, 1939.

Callahan, James Morton. Semi-Centennial History of West Virginia. Charleston, W. Va.: SemiCentennial Commission of West Virginia, 1913.

Callender, Charles. "Shawnee." In Northeast. Vol. 15 of Handbook of North American Indians. Washington: Smithsonian Institution, 1978.

Calloway, Colin G. The American Revolution in Indian Country: Crisis and Diversity in Native American Communities. New York: Cambridge University Press, 1995.

. New Worlds for All: Indians, Europeans, and the Remaking of Early America. Baltimore: Johns Hopkins University Press, 1997.

Caruso, John Anthony. The Appalachian Frontier: America's First Surge Westward. Indianapolis: Bobbs-Merrill Company, 1959.

Clark, Jerry E. The Shawnee. Lexington: University Press of Kentucky, 1993.

Clarkson, Roy B. Tumult on the Mountains: Lumbering in West Virginia, 1770-1920. Parsons, W. Va.: McClain, 1964.

Cometti, Elizabeth, and Festus P. Summers., eds. The Thirty-Fifth State: A Documentary History of West Virginia. Morgantown: West Virginia University Library, 1966.

Cook, Jeffrey B. Pricketts Fort and the Pioneers of Western Virginia: A Finding Aid. Fairmont: Prickett's Fort Memorial Foundation, n.d.

Cook, Roy Bird. Washington's Western Lands. Strasburg, Va.: Shenandoah Publishing House, 1930.

Coonts, Violet Gadd. The Western Waters: Early Settlers of Eastern Barbour County, West Virginia. Denver: Stephen P. Coonts, 1991.

Core, Earl L. The Monongalia Story: A Bicentennial History. 5 vols. Parsons, W.Va.: McClain, 1974.

Cranmer, Gibson Lamb, ed. History of Wheeling City and Ohio County, West Virginia and Representative Citizens. Chicago: Biographical Publishing Company, 1902.

Crosby, Alfred W. Ecological Imperialism: The Biological Expansion of Europe, 900-1900. Cambridge: Cambridge University Press, 1986.

Cunningham, Jr., Noble E. In Pursuit of Reason: The Life of Thomas Jefferson. New York: Ballatine Books, 1987. 
Davis, Dorothy. History of Harrison County West Virginia. Parsons, W. Va.: McClain Printing Company, 1970.

De Hass, Wills. History of the Early Settlement and Indian Wars of Western Virginia. 1851. Reprint. Parsons, W.Va.: McClain, 1989.

Dobb, Maurice. Studies in the Development of Capitalism. New York: International Publishers, 1947.

Downes, Randolph C. Council Fires on the Upper Ohio: A Narrative of Indian Affairs in the Upper Ohio Valley until 1795. Pittsburgh: University of Pittsburgh Press, 1968.

Dunaway, Wilma A. The First American Frontier: Transition to Capitalism in Southern Appalachia, 1700-1860. Chapel Hill: University of North Carolina Press, 1996.

Dunnington, George A. History and Progress of the County Marion, West Virginia. 1880. Reprint. Morgantown, W.Va.: Morgantown Printing and Binding, 1992.

Eckert, Allan W. A Sorrow in Our Heart: The Life of Tecumseh. New York: Bantam Books, 1992.

. The Frontiersmen: A Narrative. New York: Bantam Books, 1967.

Ellis, Franklin. History of Fayette County, Pennsylvania. Philadelphia: L. H. Everts, 1882.

Faragher, John Mack. Daniel Boone: The Life and Legend of an American Pioneer. New York: Henry Holt and Company, 1992.

Fischer, David Hackett. Albion's Seed: Four British Folkways in America. New York, Oxford University Press, 1989.

Ford, Thomas R., ed. The Southern Appalachian Region: A Survey. Lexington: University of Kentucky Press, 1962.

Getis, Arthur, Judith Getis, and Jerome D. Fellmann. Introduction to Geography, 6th ed. Boston: McGraw-Hill Higher Education, 1998.

Griffin, James B. "Late Prehistory of the Ohio Valley." In Northeast. Vol. 15, Handbook of North American Indians. Washington, D.C.: Smithsonian Institution, 1978.

Griswold, A. Whitney. Farming and Democracy. New Haven: Yale University Press, 1948.

Guilday, John E. Biological and Archeological Analysis of Bones from a 17th Century Indian Village (46 PU 31), Putnam County, West Virginia. Morgantown: West Virginia Geological and Economic Survey, 1971.

Hahn, Steven and Jonathan Prude, eds. The Countryside in the Age of Capitalist Transformation: Essays in the Social History of Rural America. Chapel Hill: University of North Carolina Press, 1985.

Hale, John P. Trans-Allegheny Pioneers. 3d ed. Radford, Va.: Roberta Ingles Steele, 1971.

Hartley, Dorothy. Lost Country Life. New York: Pantheon Books, 1979.

Hayak, F. A., ed. Capitalism and the Historians. Chicago: University of Chicago Press, 1954. 
Haymond, Henry. Historical Reference to Pricketts' Fort and Its Defenders. . . . N.p., n.d. . History of Harrison County West Virginia. Morgantown, W. Va.: Acme, 1910.

Heidenre ich, Conrad E. "Huron." In Northeast. Vol. 15, Handbook of North American Indians. Washington, D.C.: Smithsonian Institution, 1978.

Henlein, Paul C. Cattle Kingdom in the Ohio Valley, 1783-1860. Lexington: University of Kentucky Press, 1959.

Hoffman, Joseph E., ed. Marion County Centennial Yearbook, 1863-1963. Fairmont, W.Va.: Marion County Centennial Committee, [1963].

Howard, James H. Shawnee!: The Ceremonialism of a Native American Indian Tribe and Its Cultural Background. Athens: Ohio University Press, 1981.

Hoxie, Frederick E., ed. Encyclopedia of North American Indians. Boston: Houghton Mifflin, 1996.

Hubbard-Brown, Janet. The Shawnee. New York: Chelsea House, 1995.

Hurt, R. Douglas. Indian Agriculture in America: Prehistory to Present. Lawrence: University Press of Kansas, 1987.

Isaac, Rhys. The Transformation of Virginia, 1740-1790. New York: W. W. Norton, 1982.

Jennings, Francis. The Ambiguous Iroquois Empire: The Covenant Chain Confederation of Indian Tribes with English Colonies from Its Beginnings to the Lancaster Treaty of 1744. New York: W. W. Norton, 1984.

Johnson, Patricia Givens. General Andrew Lewis of Roanoke and Greenbrier. Blacksburg, Va.: Southern Printing Company, 1980.

Jones, Dorothy V. License for Empire: Colonialism by Treaty in Early America. Chicago: University of Chicago Press, 1982.

Josephy, Jr., Alvin M. America in 1492: The World of the Indian Peoples before the Arrival of Columbus. New York: Alfred A. Knopf, 1993.

Kendall-Lowther, Minnie. Friendship Hill: Home of Albert Gallatin. Morgantown, W. Va.: Friendship Hill Association, 1928.

Kephart, Horace. Our Southern Highlanders. New York: Outing Publishing Company, 1913.

Kulikoff, Allan. Tobacco and Slaves: The Development of Southern Cultures in the Chesapeake, 1680-1800. Chapel Hill: University of North Carolina Press, 1986.

Lamar, Howard and Leonard Thompson., eds. The Frontier in History: North America and Southern Africa Compared. New Haven: Yale University Press, 1981.

Lambert, Oscar Doane. West Virginia and Its Government. Boston: D.C. Heath, 1951.

Lemon, James T. The Best Poor Man's Country: A Geographical Study of Early Southeastern Pennsylvania. Baltimore: Johns Hopkins Press, 1972. 
Lepore, Jill. The Name of War: King Philip's War and the Origins of American Identity. New York: Vintage Books, 1998.

Lewis, Ronald L. Transformation of the Appalachian Countryside: Railroads, Deforestation, and Social Change in West Virginia, 1880-1920. Chapel Hill: University of North Carolina Press, 1998.

Lewis, Ronald L. and John C. Hennen, Jr., eds. West Virginia History: Critical Essays on the Literature. Dubuque, Iowa: Kendall/Hunt Publishing Company, 1993.

Lewis, Virgil A. A History of the Battle of Point Pleasant. Charleston, W.Va.: Tribune Printing Company, 1909.

. The Soldiery of West Virginia. Charleston, W.Va.: News-Mail Company, 1910.

. Second Biennial Report of the Department of Archives and History of the State of West Virginia. N.p.n.d., [1908?].

Leyburn, James G. The Scotch-Irish: A Social History. Chapel Hill: University of North Carolina Press, 1962.

Maxwell, Hu. The History of Randolph County, West Virginia. 1898. Reprint. Parsons, W.Va.: McClain, 1991.

McAllister, Jean Graham. A Brief History of Bath County, Virginia. Staunton: McClure, 1920.

McDaniel, L'lora C. The History and Genealogy of the Ancestors of John M. Tomey and Catharine M. Prickett and Their Descendants. N.p., n.d.

McMichael, Edward V. Introduction to West Virginia Archeology. 2d ed., rev. Morgantown: West Virginia Geological and Economic Survey, 1968.

McNeill, G. D. Tales of Pocahontas County. Parsons, W.Va.: McClain, 1991.

McRaven, Charles. Building with Stone. Pownal, Vt.: Garden Way Publishing, 1989.

McWhiney, Grady. Cracker Culture: Celtic Ways in the Old South. Tuscaloosa, Ala.: University of Alabama Press, 1988.

Miller, Kimberlee. Descendants of Capt. Jacob Prickett, Sr. Fairmont, W.Va.: Jacob's Meadow, 1996.

Mitchell, Robert D. ed. Appalachian Frontiers: Settlement, Society, and Development in the Preindustrial Era. Lexington: University Press of Kentucky, 1991.

Commercialism and Frontier: Perspectives on the Early Shenandoah Valley. Charlottesville: University Press of Virginia, 1977.

Morton, Frederic. The Story of Winchester in Virginia: The Oldest Town in the Shenandoah Valley. Strasburg, Va.: Shenandoah Publishing House, 1925.

Morton, Oren F. Annals of Bath County, Virginia. Staunton, Va: McClure, 1917.

Morton, Richard L. Colonial Virginia. 2 vols. Chapel Hill: University of North Carolina Press, 1960. 
Nabokov, Peter and Dean Snow. "Farmers of the Woodlands." In America in 1492: The World of the Indian Peoples before the Arrival of Columbus. edited by Alvin M. Josephy, Jr. New York: Alfred A. Knopf, 1993.

Odle, Mark. "Tools and Techniques of Bark Tanning." In The Book of Buckskinning VII. edited by William H. Scurlock. Texarkana, Tex.: Scurlock Publishing, 1995.

Perkins, Elizabeth A. Border Life: Experience and Memory in the Revolutionary Ohio Valley. Chapel Hill: University of North Carolina Press, 1998.

Pocahontas County Historical Society. History of Pocahontas County West Virginia 1981. Marlinton, W.Va.: Pocahontas County Historical Society, 1981.

Price, William T. Historical Sketches of Pocahontas County, West Virginia. Marlinton, W.Va: Price Brothers, 1901.

Pritts, Kim Derek. Ginseng: How to Find, Grow, and Use America's Gold. Mechanicsburg, Pa.: Stackpole Books, 1995.

Pudup, Mary Beth, Dwight B. Billings, and Altina L. Waller., eds. Appalachia in the Making: The Mountain South in the Nineteenth Century. Chapel Hill, N.C.: University of North Carolina Press, 1995.

Puglisi, Michael J., ed. Diversity and Accommodation: Essays on the Cultural Composition of the Virginia Frontier. Knoxville: University of Tennessee Press, 1997.

Ragsdale, Bruce A. The Planters' Republic: The Search for Economic Independence in Revolutionary Virginia. Madison, Wis.: Madison House, 1996.

Rasmussen, Barbara. Absentee Landowning and Exploitation in West Virginia, 1760-1920. Lexington: University Press of Kentucky, 1994.

Rice, Otis K. The Allegheny Frontier: West Virginia Beginnings, 1730-1830. Lexington: University Press of Kentucky, 1970. . A History of Greenbrier County. Lewisburg, W.Va.: Greenbrier Historical Society, 1986.

Rice, Otis K. and Stephen W. Brown. West Virginia: A History. Lexington, University Press of Kentucky, 1993.

Salstrom, Paul. Appalachia's Path to Dependency: Rethinking a Region's Economic History, 1730-1940. Lexington: University Press of Kentucky, 1994.

. "Economic History of West Virg inia: A Critical Essay." In West Virginia History: Critical Essays on the Literature, edited by Ronald L. Lewis and John C. Hennen, Jr. Dubuque, Iowa: Kendall/Hunt, 1993.

Schwaegel, Bruce. "Brain Tanning Buckskin." In The Book of Buckskinning III, edited by William H. Scurlock. Texarkana, Tex.: Rebel Publishing, 1985.

Shapiro, Henry D. Appalachia on Our Mind: The Southern Mountains and Mountaineers in the American Consciousness, 1870-1920. Chapel Hill: University of North Carolina Press, 1978.

Sheridan, Richard B. Sugar and Slavery: An Economic History of the British West Indies, 16231775. Baltimore: Johns Hopkins University Press, 1973. 
Smith, Henry Nash. Virgin Land: The American West as Symbol and Myth. Cambridge: Harvard University Press, 1950.

Sosin, Jack M. The Revolutionary Frontier, 1763-1783. New Y ork: Holt, Rinehart and Winston, 1967.

Whitehall and the Wilderness: The Middle West in British Colonial Policy, 1760-1775. Lincoln: University of Nebraska Press, 1961.

Thernstrom, Stephan. A History of the American People. Vol. 1, To 1877. New York: Harcourt Brace Jovanovich, 1984.

Thom, James Alexander. Panther in the Sky. New York: Ballantine Books, 1989.

Thompson, James Westfall. A History of Livestock Raising in the United States, 1607-1860. Agricultural History Series, no. 5. 1942. Reprint. Wilmington, Del.: Scholarly Resources, 1973.

Tillson, Jr., Albert H. Gentry and Common Folk: Political Culture on a Virginia Frontier, 1740 1789. Lexington: University Press of Kentucky, 1991.

Trigger, Bruce G. The Huron: Farmers of the North. 2d ed. Fort Worth: Harcourt Brace Jovanovich College Publishers, 1990.

Van Every, Dale. Forth to the Wilderness: The First American Frontier, 1754-1774. New York: Morrow, 1961.

Verhoeff, Mary. The Kentucky Mountains, Transportation and Commerce, 1750-1911. Filson Club Publication 26. Louisville: John P. Morton, 1911.

Wallace, Anthony F. C. The Death and Rebirth of the Seneca. New York: Vintage Books, 1969.

Wallace, Paul A. W. Indians in Pennsylvania. Harrisburg: Pennsylvania Historical and Museum Commission, 1961.

White, Richard. The Roots of Dependency: Subsistence, Environment, and Social Change among the Choctaws, Pawnees, and Navajos. Lincoln: University of Nebraska Press, 1983.

Wiebe, Robert H. The Opening of American Society. New York: Alfred A. Knopf, 1984.

Wilcox, William J. Pricketts Fort: How and Why It Came to Be! N.p., n.d.

Williamson, J. W., ed. An Appalachian Symposium: Essays Written in Honor of Cratis D. Williams. Boone, N.C.: Appalachian State University Press, 1977.

Withers, Alexander Scott. Chronicles of Border Warfare. Edited by Reuben Gold Thwaites. 1895. Reprint. Parsons, W.Va.: McClain, 1989.

Wright, J. E., and Doris S. Corbett. Pioneer Life in Western Pennsylvania. Pittsburgh: University of Pittsburgh Press, 1940. 


\section{$\underline{\text { Articles }}$}

Baker, Stanley W. "An Iron Trade Axe from the Neale's Landing Site, 46WD39, on Blennerhassett Island." West Virginia Archeologist 36 (1988): 40-53.

"Neale's Landing Site Ceramics: A Perspective on the Protohistoric Period from Blennerhassett Island." West Virginia Archeologist 40 (1988): 40-53.

Billings, Dwight, Kathleen Blee, and Louis Swans on. "Culture, Family, and Community in Preindustrial Appalachia." Appalachian Journal: A Regional Studies Review 13 (1986): 15470 .

Cook, Roy Bird. "Virginia frontier Defenses: 1719-1795." West Virginia History. 1 (1940):119130.

[Fallom, Robert]. "Explorations Beyond the Mountains." William and Mary Quarterly. 15 (1907): 234-41.

Fowler, Daniel B. "An Old Shawnee Town in West Virginia." West Virginia Archeologist 28 (1979): 24-29.

Handley, Harry E. "Beginnings of the Occupation of the Greenbrier Area by the English." Journal of the Greenbrier Historical Society 1 (1963): 5-7.

$\frac{14}{14}$. "The Mathews Trading Post." Journal of the Greenbrier Historical Society 1 (1963): 8-

Hart, John Fraser. "Land Rotation in Appalachia." Geographical Review 67 (1977): 148-66.

Hood, Adrienne D. "The Material World of Cloth: Production and Use in Eighteenth-Century Rural Pennsylvania." William and Mary Quarterly 53 (1996): 43-66.

Hsiung, David C. "How Isolated Was Appalachia?: Upper East Tennessee, 1780-1 835." Appalachian Journal 16 (1989): 336-49.

Kulikoff, Allan. "Households and Markets: Toward a New Synthesis of American Agrarian History." William and Mary Quarterly 50 (1993): 342-55.

. "The Transition to Capitalism in Rural America." William and Mary Quarterly 3d ser., 46 (1989): 120-44.

Lewis, Ronald L., and Dwight B. Billings. "Appalachian Culture and Economic Development: A Retrospective View on the Theory and Literature." Journal of Appalachian Studies 3 (1997): 3-42.

Lilly, Paul R. "The Drovers." Journal of the Greenbrier Historical Society 4 (1986): 13-18.

McDonald, Forrest and Grady McWhiney. "The Antebellum Southern Herdsman: A Reinterpretation." Journal of Southern History 41 (1975): 147-66.

McMahon, Sarah F. "A Comfortable Subsistence: The Changing Composition of Diet in Rural New England, 1620-1840." William and Mary Quarterly, 3d ser., 42 (1985): 26-65.

Merrill, Michael. "Putting 'Capitalism' in Its Place: A Review of Recent Literature." William and Mary Quarterly, 3d ser., 52 (1995): 315-26. 
Moxley, Ronald W. "The Orchard Site: A Proto-Historic Fort Ancient Site in Mason County, West Virginia." West Virginia Archeologist 40 (1988): 32-41.

Otto, J. S., and N. E. Anderson. "Slash-and-Burn Cultivation in the Highlands South: A Problem in Comparative Agricultural History." Comparative Studies in society and History 24 (1982: 131-47.

Perkins, Elizabeth A. "The Consumer Frontier: Household Consumption in Early Kentucky." The Journal of American History 78 (1991): 486-510.

Salstrom, Paul. "Appalachia's Informal Economy and the Transition to Capitalism." Journal of Appalachian Studies 2 (1996): 213-33.

. "Subsistence-Barter-and-Bor row Systems: An Approach to West Virginia's Economic History." West Virginia History 51 (1992): 45-53.

Shapiro McDonald, Ellen and Forrest McDonald. "The Ethnic Origens of the American People, 1790." William and Mary Quarterly, 37 (1980): 179-99.

Swope, Frances Alderson, comp. "The Mathews Trading Post Ledger, 1771-1779." Journal of the Greenbrier Historical Society 4 (1984): 20-60.

Swope, Kenneth D. "Ginseng." Journal of the Greenbrier Historical Society 4 (1982): 107-112.

Vickers, Daniel. "Competency and Competition: Economic Culture in Early America." William and Mary Quarterly 47 (1990): 13-29.

Voegelin, Erminie Wheeler. "The Place of Agriculture in the Subsistence Economy of the Shawnee." Papers of the Michigan Academy of Science, Arts and Letters 26 (1940): 513-20.

Walls, David S., and Dwight Billings. "The Sociology of Southern Appalachia." Appalachian Journal 5 (1977): 131-44.

\section{$\underline{\text { Dissertations and Theses }}$}

Barnes, L. Diane. "Avenues to a Market Economy: Harrison County, West Virginia, to 1860." Master's thesis, West Virginia University, 1995.

Workman, Michael E. "Political Culture and the Coal Economy in the Upper Monongahela Region: 1776-1933." Ph.D. diss., West Virginia University, 1995.

\section{$\underline{\text { Internet }}$}

Maslowski, Robert F. "Prehistoric People of the Kanawha Valley." <http://www.wvlc.wvnet.edu/wvarl/srbk.html>, 13 September 1997. 
John M. Boback, a graduate student at West Virginia University, graduated with a Bachelor of Arts degree in History and Political Science from Alders on-Bro addus College in 1988. He is married and has two children. 